\title{
TRANSITION FROM AOGA AMATA TO SCHOOL: CASE STUDIES IN THE WELLINGTON REGION
}

$372 \cdot 182999462$ MAL

by

Le'autuli' ilagi Malaeta Faasapisapi Sauvao

A thesis submitted to Victoria University of Wellington in partial fulfilment of the requirements for the degree of Master of Education.

Victoria University of Wellington

1999

WELLINGTON COLLEGE OF EDUCATION

LIBRARY 


\section{COPYRIGHT CLEARANCE}

This copy has been made with the permission of the author on the understanding that the following conditions will be observed:

1. The thesis will be used only in the library/institution which has requested it.

2. It is required for private research only.

3. Without written permission from the author, it will not be used for any commercial purpose and no reproductions will be made from it.

4. Author of thesis, their title, faculty and University will be cited in any work making use of the material in this thesis. 


\section{ABSTRACT}

Background The rapid increase in the number of Samoan children receiving early childhood education in their heritage language through the Aoga Amata movement has prompted the researcher to examine how continuity is being handled during the transition to primary schooling. During 1996-7, I interviewed parents, teachers, principals and children about the transition from Aoga Amata programmes to junior class programmes in fourteen primary schools. In addition, I gathered descriptions of how parents viewed the nature and the quality of Aoga Amata programmes, and how teachers and principals viewed issues of language maintenance. I also asked children to reflect on their Aoga Amata experience and then engage in performance tasks that provided me with an opportunity to gauge their spoken proficiency in Samoan.

Aim The primary aim of the study was to gather information from parents, children, teachers and principals about the way the transition to school was organised for Aoga Amata children.

Sampling procedures I used a community network approach to gain access to a pool of twenty recent graduates of Aoga Amata and their receiving schools. In addition, I chose six childret for case study purposes because of the interesting circumstance each child represented. Thirty-nine parents, fourteen teachers and fourteen principals completed the sample.

Procedures I used structured interviews, questionnaire versions of the structured interviews, and performance tasks in order to collect information. I asked about the strategies used to cope with the transition to primary school; the impact of the transition on children, the perceptions of parents about Aoga Amata programmes, perceptions of teachers about the transition to primary school, and the factors thought by stakeholders to be contributing to the maintenance of the Samoan language in school. The procedures used to gather information were carried out using culturally appropriate communication processes that made use of faafeiloaiga faa Samoa (cultural greetings), faaaloalo (respect and supply of food), faamalie ona o ni itu e faalavelavea ai le suesuega (acknowledgement of intrusion) and lauga faafetai/faamavae (speeches of appreciation and farewell). 
Results Only one Aoga Amata/school partnership had a comprehensive programme where the graduates of the Aoga Amata were received into a bilingual programme taught by a native speaker of Samoan. The Aoga Amata was on the school grounds and this enabled linkages to develop over a period of time between its staff, the teachers at the school, the children, and the children's families. When children were received into schools where there was no continuity of language and curriculum, the transition was perceived as less satisfactory, especially in the early days of the transition. Compared to children who attended other early childhood educational centres, or remained at home, children who had attended an Aoga Amata programme were generally perceived by most teachers and parents as having more developed literacy, numeracy, and social skills. Schools varied in the position they took on language maintenance and on the actions that they were prepared to take. Lack of funding, lack of trained Samoan teachers, and a view that the school's cultural activities were sufficient were all reasons given for an absence of language maintenance.

Conclusion There is lack of an agreed understanding of what is necessary for successful transition to school in the case of Aoga Amata children. Stakeholders in the children's education will need to target policy, strategies, and standards to guide continuity between home, Aoga Amata, school and community. 


\section{ACKNOWLEDGEMENTS}

Ua atue le tautai ina ua a'e manuia le faiva, ma ua fagaeetia ai le agaga ona o le ufi a Sina na tuli i mataga gau i taimi o faigata, lenei ua tini lau i le si'ui o le faamoemoe. Ua moni ai le muagagana , "O le faamoemoe ua taunuu o le laau lea o le soifua". E mua ai le viiga i le Atua ona o lona mana fesoasoani ma lona faatasi mai i lenei taumafaiga, i taimi na luluti ai tiga o le faavaivai loto ma lolofi mai ai fili o le augata, ma lu'itau e tele o tiute tauave faa faalapotopotoga, faa le galuega, faa le ekalesia, faa le a'oa'oga, faa le nuu ma faa le aiga. Ua ou talitonuina ai pea se tasi fuaitau faa le Tusi Paia, "E leai se mea e faigata i le Atua" (Nothing is impossible with God).

I would like to acknowledge the support received from many people during the course of the project:

- My supervisor Dr Ana Koloto for her patient understanding, scholarly advice, and constant encouragement. Malo aupito Ana!

- My friends, colleagues, and university staff who have helped and supported me during the project. I particularly thank Mele Nonumalo for contacting Lower Hutt parents for meetings, Saili Aokuso for sharing in professional discussions, Evedina Fuli for her friendly advice, and Jim Dickie for helping me edit the final draft of the thesis.

- My sister Fulisia, her husband Tuaoimalii Faavae and their children who cared and nursed our elderly parents in Samoa on my behalf.

- My brothers, sisters and my extended family. Faafetai lagolago e ala i talosaga molia.

I am especially indebted to the children, parents, teachers and principals of the fourteen schools who took part in the study. 
I will always be grateful to my parents Filoi and Taotua Potoa'e, and Popo Tanielu for the tapuaiga. Malo fai tatalo! I am forever thankful that my dearest mother Filoi has lived to see this work completed.

The memories of my children, Ainslie Maxene, Pauline Filoi Jr., Chanel Vaatausili Jr., and my husband Tanuvasa Vaatausili Sauvao have always been with me during my University study. Faamalo tapua'i! Ia suluia pea outou uma i le malamalama o fofoga alofa o le Atua, ma ia tumau le lasi o ana faamanuiaga i o outou luga e le aunoa. 


\section{DEDICATION}

This thesis is dedicated to my children

Ainslie Maxene, Chanel Tausili Jr. and Pauline Filoi Jr 
Pages

Abstract

Acknowledgements

iv

Dedication

vi

Table of Contents

vii

List of Tables

$\mathrm{X}$

Chapter 1 INTRODUCTION

1.1 Introduction

1.2 Background and researcher's position 2

1.3 Rationale for the present study

1.4 Research questions

1.5 Theoretical framework

1.6 Overview of chapters

Chapter 2 LITERATURE REVIEW

2.1 Introduction 11

2.2 Early Childhood education in New Zealand - 11 Te Kohanga Reo

2.3 The Development of Pacific Islands Language $13=$ Nests

2.4 The Development of Aoga Amata

2.5 The Transition to School

2.6 Summary

Chapter 3 RESEARCH DESIGN AND METHODOLOGY

3.1 Introduction 28

3.2 Research Design 29

3.3 Phase One: Literature review Search 29

3.4 Phase Two: Development of interview schedule 30

3.5 Phase Three: Main Study 31

3.6 Phase Four: Data analysis 38

3.7 Phase Five: Writing of the research 40

$=: 3.8$ Problems and Difficulties 40

3.9 Summary 42 
Chapter 4

Chapter 5

Chapter 6

\section{RESULTS}

4.1 Introduction 43

4.2 Coping with the transition

4.3 Perceptions of the Aoga Amata programmes

4.4 Transition to primary school

4.5 Factors affecting language maintenance

4.6 Summary and Discussion

\section{CASE STUDIES}

5.1 Introduction

59

5.2 Case Study 1: A female student who experienced 60 Samoan Language in school

5.3 Case Study 2: A male student who experienced 64 Samoan Language in school

5.4 Case Study 3: A female student who experienced 67 no Samoan Language in school

5.5 Case Study 4: A male student who experienced $\quad 72$ no Samoan Language in school

5.6 Case Study 5: A female student who experienced 76 no Samoan Language in school

5.7 Case Study 6: A female student who experienced 80 no Samoan Language in school

5.8 Summary and Discussion

\section{CONCLUSION}

6. 1 Introduction

6.2 Main Findings from the Interviews

6.3 Main Findings from Case Studies

6.4

Conclusions

6.5

Limitations

95

6.6 Implications of Transition Programmes 95

6.7 Implications for Future Research 97

6.8 Concluding thoughts 98 


\section{APPENDICES}

Appendix A Interview schedules

A1 A sample of interview questions for parents

A2 Interview schedule for children

A3 A copy of the interview questions for principals

A4 A copy of the interview questions for teachers

Appendix B Information provided to participants

B1 A sample letter to and consent form for parents

B2 A sample letter to principals

Appendix C Performance Tasks for children

GLOSSARY 


\section{LIST OF TABLES}

2A Pacific Islands early childhood enrolments by age 1990-1997

2B Distribution of Pacific Islands early childhood centres

3A Sequencing of the phases $\quad 29$

3B An example of a question sequence 31

3C Summary of children selected for the study 32

3D Order of interviews carried out in fourteen schools 33

3E Order of interviews carried out in schools 35

$3 \mathrm{~F} \quad$ Sequential order within the interview procedure and for recording data $\quad 38$

3G Data sorting card

5A Summary of case study children $\quad 59$

5B Miriama's subjects assessment 61

5C Miriama's overall assessment in development $\quad 62$

5D Talia's subject assessment 66

5E Puipuiau's overall assessment of development $\quad 70$

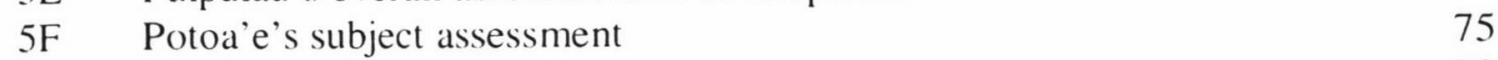

5G Maxine's subject assessment $\quad 78$

5H Maxine's overall assessment of development $\quad 79$

5I Sia's subjects assessment 81

5J Sia's overall assessment of development 81 


\title{
CHAPTER ONE
}

\section{INTRODUCTION}

\author{
O le laupaega o vaega autu o le suesuega \\ Main points of the study are outlined in sequence
}

\subsection{Introduction}

Internationally, it has been accepted as axiomatic that a child's first educational experiences should be in the mother tongue (UNESCO, 1953). In addressing this viewpoint, multilingual countries have encouraged the development of early childhood educational services by supporting local initiatives by particular speech communities. In New Zealand, Maori communities established Te Kohanga Reo (Maori Language Nests) from 1982 onwards, and this pattern was later followed by Pacific Islands communities. From 1985 Samoan churches have been particularly active in this respect. For example, by 1997, seventy-six Aoga Amata (Samoan Language Nests) were registered with the national Aoga Amata association (ie. SA'ASIA -Sosaiete a Aoga Amata i Aotearoa). Twenty were licensed as childcare centres and fifty were funded by the Early Childhood Development Unit (Burgess, 1997).

The rapid increase in the establishment of Aoga Amata in New Zealand has been an important reason for the increased participation rates of Samoan children in early childhood education (see chapter 2). Not only did the Aoga Amata movement bring early childhood education principles into Samoan homes, it also prepared the way for parents to reconsider the role of language and culture in the educational development of their children.

Despite the movement being thirteen years old, very little has been recorded by way of published material about the transition of Samoan children from Aoga Amata to primary schools. Moreover, as a research student and a teacher, I was interested to find out about the 
educational progress of Samoan children who had graduated from Aoga Amata. These two reasons provide the rationale for the present project.

The focus of the study is on twenty Samoan children who attended Aoga Amata in the Wellington region from 1988-1995. The study gathers information about their preschool experience and their transition to primary school. It examines the parents' perceptions of their children's Aoga Amata experience and the Aoga Amata programmes. The study also identifies the teachers' perceptions of the transition of the children and their subsequent progress in primary education. It also examines the principals' opinions about the provision and nonprovision of Samoan language in the school curriculum.

Given that an increasing number of children from the Aoga Amata are attending junior classes, the study also discusses the perceptions of principals as to how the language needs of Samoan children are best addressed within their schools.

\subsection{Background and Researcher's Position}

It has been said that one of the few universals of childhood in western society is the transition to school (Ramey \& Ramey,1994). After the family, the school is likely to have the most profound influence on the course of a child's life.

In most cultures the time to begin school has been considered a significant milestone in the lives of young children. The child's first day at school marks the commencement of 'formal learning', while the years prior to school entry are described as 'informal learning', a time when children play and learn incidentally (Cullen, 1998; Briggs and Potter, 1990; David, 1990).

Few studies have asked the children themselves how they feel about starting school. Instead this question has been addressed to adults who are playing a significant role in the children's lives. For example, Renwick (1984) asked parents, pre-school teachers and new-entrant teachers what they thought New Zealand five-year-olds expected school to be like. The adults 
believed that most children looked forward to school with pleasure, tinged with uncertainty about the unknown.

My role as a visiting lecturer and adviser for the Wellington Multicultural Educational Resource Centre from 1990-1995 involved me in assisting teachers and children in respect to educational needs, resources, and teaching and learning strategies. These visits covered the early childhood, primary, secondary and tertiary sections of the education system. During the visits to primary schools, I observed that some Samoan children who arrived from Aoga Amata had few difficulties in coping with their new primary school learning environment because they came with a sound basic knowledge of literacy and numeracy, and proficient social skills. However, there were also some monolingual children (Samoan language speaking only) arriving from Aoga Amata who did experience initial difficulty in adjusting to the use of English in the junior classroom. The only help I observed during these visits was the provision of a person (usually another Samoan child such as a brother/sister/cousin) who was withdrawn from another class to assist the new child with her/his work.

Withdrawal for this reason became a cause of concern for the older children and their teachers, because of the work missed from their own class programmes. Parents, thought that the arrangement was unfair, and considered that it was the school's responsibility to provide an appropriate provision.

My involvement in community educational projects in the Wellington Samoan community has enabled me to understand the reasons why many Samoan parents prefer to send their children to kindergartens or other general early childhood education centres, and the dilemas they face in making the decision. Some parents send their children to local kindergartens or play centres so that they develop two first languages during early childhood; others make the decision on the relative value of the vernacular in relation to a language of wider currency as Kulick (1992:12) has remarked: 
The parents consider that their children "don't need" to learn the Vernacular to get by in society or they are concerned the child's school language might suffer if he or she speaks the vernacular.

These experiences and observations have motivated me as a Samoan researcher to undertake this study.

\subsection{Rationale for the Present Study}

As a Samoan research student and teacher, I was pleased that the Ministry of Education put out a discussion paper called, Ko e ako a e kakai Pasifika - Plan for Developing Pacific Islands Education in New Zealand, (1996). The executive summary of the document states that children of Pacific Islands origin currently constitute $7 \%$ of the school population, estimated to rise to $11 \%$ by the year 2031 .

The Ministry of Education, by developing a strategic plan for Pacific Islands' education, has made suggestions as to how participation levels and educational achievement could be improved across all sectors of the education system. The document backgrounds the comparatively low achievement of Pacific Islands' children and argues that it is desirable to have active, high profile policy development for Pacific Islands' early childhood education, research projects for identifying and evaluating best practice, achievement initiatives at the community - school level, and the development of alternative structures for enhancing Pacific Islands education (Ministry of Education, 1996).

I always admire the New Zealand born Samoans of our church community who are fluent in the Samoan language. They are often noticeable as confident speakers of both Samoan and English. As with all children, the language development of New Zealand born Samoans begins in the family and the languages used in the day-to-day interactions with the children and among the adults. Where this language is Samoan, spoken by native speakers of Samoan, an excellent basis is provided for the development of the heritage language for children born in New Zealand. Such children are also inevitably exposed to English through their contacts 
with other children and activities in the wider community. Thus two first languages can be developing side by side during the pre-school years. As linguists such as Holmes (1993), Cummins (1986), Skutnabb-Kangas and Toukomaa (1976) have emphasised that people who speak two or more languages are more advantaged than those with one.

\section{Home languages}

Eighteen of the children interviewed in the present study spoke Samoan at home because their parents and grandparents were Samoan. Two of the children in the study had parents who spoke different first languages and therefore the child spoke both Samoan and English at home. Although one child had a Maori mother and a Samoan father, English was their preferred language at home, as the mother was not a fluent speaker of Maori and could not use Samoan. Yet the parents sent their child to an Aoga Amata in the hope that the child would build on his language experiences with his father and develop two first languages. There were also parents in the study who were non-Samoan speakers, yet who wanted their children to acquire Samoan and to maintain their cultural heritage.

Involvement in the life of the church also encouraged the children in their Samoan language development because the church activities were usually conducted in Samoan.

\section{Parents' perceptions of Aoga Amata programmes}

The study will discuss the opinions of a sample of parents regarding the curriculum and the services offered by the local Aoga Amata. Assuming that the opinions are abstracted from particular encounters with Aoga Amata programmes, and not my status as an investigator, the opinions are likely to represent the covert effects on family life from using language planning in early childhood education. The opinions held by parents about Aoga Amata programmes are likely to shape the parents involvement in the movement, the child-rearing practices adopted at home, and the steps taken to ensure continuity in the child's education regarding the curriculum and the services offered by the local Aoga Amata. 


\section{Transition to primary schools which teach Samoan language}

The study will discuss the way Aoga Amata children adjust to the transition to primary school and how their language develops under the different types of provision provided by schools. The particular interest is in the progress made by children from Aoga Amata who moved to a primary school which, caters for the continuity of Samoan language. In contrast, many children were enrolled in schools with English-only programmes in such cases, Aoga Amata graduates might find it difficult to communicate with teachers and other children during the early stages of transition to school. The case studies in chapter five detail the investigation of children under different school policies.

\section{$1.4 \quad$ Research Questions}

The following five questions guide the research plan and the collection of data. The procedures used in the research are described in chapter three.

I How do Samoan speaking children from Aoga Amata cope with the transition to primary schools?

2 What impact does the transition have on the children?

3 What are the parents' perceptions of Aoga Amata programmes and the management of the transition?

$4 \quad$ What are the teachers' perceptions of the transition to primary schools?

5 What factors contribute to the maintenance of Samoan language in schools? 
This section outlines my own Samoan perspective on education. It also outlines the claims associated with transition research in general, and how the claims relate to the position of Aoga Amata children entering primary schools in New Zealand.

\section{Samoan perspective on education}

Traditionally, the education of young children has occurred within the aiga (extended family), within the church, and within village settings. Children were nurtured within the daily activities of the home and at the hands of many people. The biblical injunction to teach the child according to God's ways so that, in growing up, the child will never part from those ways (Proverbs 22:6) has created the expectation that a Christian up-bringing would lead to long term benefits in a child's development. Within the home, learning is a way of living. Learning is not separate from life itself. Observing, listening, experimenting, cooperating, contributing, initiating, remembering, and respecting are the everyday-lived experiences of young children as they play and join the work within family and village settings.

When social and economic circumstances require the separation of children from the everyday work of the family, the separation is minimalised, by taking the child into the arms of the Anga Amata family. The teachers are mostly known to the children through membership of a church or through the complex interrelations of families within the community. There is continuity in language, culture, and Christian activity between the child's home and the Aoga Amata. The child's early education is kept within the arms of the family, the church, and the child's immediate community.

\section{The transition perspectives}

Transition is inevitably in the life of a child and is an important part of development. However, the sensitive management of change should be guided by the observation that change should be sufficient to be stimulating but not so drastic as to cause shock (Cleave, 
Jowetl and Bate. 1982). For some children the transition from home to school is a happy and successful one. for others the experience can be one of anxiety and confusion (Robson and Smedley, 1996).

Blatchford, Battle, and Mays (1982) found that. after children entered a nursery, over half of the mothers they interviewed admitted to experiencing various degrees of stress. This is understandable in situations where the child has found the transition difficult. Blatchford, however. found that even where a child had found the transition a happy experience, mothers often said that they had felt distressed or anxious.

The development of language in young children during the first year in primary school is closely related to the literacy programme. Experiences with books invariably is in English because of the richness of the literature that is available. However, there is no reason why literacy experiences in Samoan should not accompany literacy development in English. Learning Media, the publishing arm of the Ministry of Education has recognised the biliteracy needs of Samoan children through the Tupu Series.

It is a widely accepted principle that a child in school should be instructed at first in his mother-tongue while s/he gains oral control of the language of instruction. Such a policy is usually impracticable in multilingual settings where children of several ethnic groups enter one school system. In some urban schools, for example, the languages of the Pacific, such as Samoan, Tongan. Niuean, Fijian, Cook Island Maori and Tokelauan, exist as mother-tongues in many classrooms, while English is the language of instruction.

Due to Government immigration policies, and the population growth of Pacific communities in New Zealand, an increasing number of children come to school to learn in a language different from their home languages. New Zealand is a multicultural society our children reflect this, and the education system.

Sutherland (1989) states that the children who come from Aoga Amata have a rich conceptual hase in Samoan, and make the transition to English with ease. They are secure in their first 
language and are highly interactive in it. Samoan has become for them, a legitimate language within the school, and also a legitimate language for learning.

In the case of Maori children, Kaai (1990) is of the view that, in making the transition from Te Kohanga Reo to school. Matori children need classrooms that continue to use and develop the processes of Te Kohanga Reo. This observation is equally relevant for children making the Iransition between Aoga Amata and primary school.

\subsection{Overview of Chapters}

Chapter two outlines the history of the Aoga Amata movement and its place in Pacific Islands education in New Zealand. The chapter also reviews research on the transition from preschool to primary school from the perspective of both New Zealand and other countries. In addition, it reviews the literature about the importance of bilingualism as well as the factors affecting the maintenance and development of a heritage language.

Chapter three outlines the methodology and the research design. In particular, it provides a brief defcription of the children and how they were selected. The interviews, as well the problems and difficulties observed during the field -work, are also explained in this chapter.

Chapter four outlines the results of the interviews and suggests answers to the research questions based on information gathered from twenty students, fourteen teachers, fourteen principals, and thirty-nine parents.

Chapter five discusses six case studies: two children, one male one female. who attended primary schools which provided for the teaching of Samoan language; two children, one male one female. who attended primary schools which did not provide for the Samoan language; and the remaining two children, both females, who attended primary schools that also did not provide for the teaching of Samoan. The two girls displayed differences in their learning progress. 
Chapter six summarises the main findings. The chapter then draws conclusions and discusses implications of the findings for curriculum processes, planning, resource development, parent support, the church community, teacher education, school organisation, and future research.

Each chapter is headed with a Samoan proverb that alludes to the topic of the chapter and gives a significant meaning and Samoan flavour to the research. 


\title{
CHAPTER TWO
}

\section{LITERATURE REVIEW}

\author{
Lafo le upega i le loloto e maua ai i'a laulelei \\ Throw the net to the deep and you will catch good fish.
}

\subsection{Introduction}

The initial sections of this chapter focus on the development of relevant early childhood education services in New Zealand. In particular section 2.2 briefly outlines the development of Te Kohanga Reo. This is followed by a description of the establishment of Pacific Island language nests in Aotearoa (2.3) and the development of Aoga Amata movement (2.4). The next section, 2.5, reviews studies on Children's transition from preschool to primary schools. Section 2.6 provides a summary for the chapter.

\subsection{Early childhood education in New Zealand -Te Kohanga Reo}

Historically, early childhood education in New Zealand has developed in an adhoc manner which consequently resulted in the establishment of a diverse number of services (May, 1990; Meads, 1988). These services include childcare, playcentre, kindergarten, Barnardos, Te Kohanga Reo and Pacific Islands language nests. As a country, New Zealand has increasingly come to value early childhood education (Wylie, 1996). It is beyond the scope of this review to dicuss in details the development of all of the above early childhood services. However, the emphasis will be on a brief outline of the development of the Te Kohanga Reo, the service that is of particular significant to this study. 


\section{Te Kohanga Reo and Maori Language revival}

Te Kohanga Reo is one of the most dynamic and innovative educational programmes in the country. Since, the establishment of the first Kohanga Reo (the language nest) in April 1982 at Wainuiomata (Jenkins, 1994), the number of Te Kohanga Reo increased very rapidly. By 1987, the number of Te Kohanga Reo had reached 513 and in 1993 the number reached 809 surpassing both kindergartens (582) and playcentres (577) (Ministry of Education, 1994).

Te Kohanga Reo is a programme, which aims to offer quality child rearing in a Maori whanau environment where te reo Maori is the language of instruction. The whanau provides the well-spring for love, care and spiritual growth. Te Kohanga Reo also aims to address the decline of Maori speaking people in New Zealand (Te Kohanga Reo Resource Manual, 1985; Hohepa, 1993). As well as to encourage Maori people to take and lead initiatives and make a positive contribution to the wider New Zealand society (Te Kohanga Reo Resource Manual, 1985).

Given that Te Reo Maori is the medium of communication and instruction it is inextricably bound to Tikanga Maori; Maori concepts, values, beliefs and practices. The principles and philosophy of Te Kohanga Reo are based on Tikanga Maori. It has been argued that Te Kohanga Reo has a distinct Maori pedagogy where the social and cognitive skills of children are developed using Te Reo Maori (Ka’ai, 1990).

\section{Te Kohanga Reo and educational disparities}

Te Kohanga Reo arose from the need to address first and foremost, the crisis facing Maori language. Education achievement levels of Maori children was also a major consideration for Te Kohanga Reo.

In the last 20 years a growing awareness of Maori educational underachievement has lead to a number of enquiries and reassessment of the suitability of the kind of education being provided for Maori children. The disparity in education achievement between Maori and

Pakeha identified by the Hunn report in 1960 is as intractable as ever. Against 15-19 year olds in the 1981 census $79 \%$ of Maori children had left school before $6^{\text {th }}$ form compared 
with $62 \%$ non-Maori. The common response of Pakeha society has always been to blame the children, blame their parents, blame the culture, blame everyone except the system under which they were being educated. The most successful Maori response to obtain control and power over the decision making processes affecting their children's lives has been Te Kohanga Reo (Kaai, 1990).

As children leave Te Kohanga Reo, parents shop around for schools, seeking out those that offer bilingual continuity. In cases where no bilingual programme is offered many parents hold back their children in the Kohanga for a further year. It should be noted, that as we enter into the era of declining rolls due to the falling birth rate, primary schools will be forced to become bilingual to attract Kohanga children and maintain their grading and staffing levels. The seizing of power by Maori parents in this area will spread to the other sectors of education.

\subsection{The Development of Pacific Islands Language Nests:}

In the 1991 census, the Pacific Islands population was identified as the fastest growing population in New Zealand, (O'Rourke, 1991). The number of Pacific Island residents in New Zealand in the decade 1956-1966 had more than trebled by the mid-seventies as a result of both heavy immigration and a relatively high rate of natural increase (Barney, 1975). Although immigration has now slowed, the natural rate of increase remains high and is responsible for the present demographic trends. Between 1990 and 1997, Pacific Islands enrolments early childhood rose by 63 percent, (Ministry of Education, 1997) with the largest increases shown in the younger age groups, see Table $2 \mathrm{~A}$ below. The only one age group to show a decrease in number from 1990-1997 was five-year-old children. 
Table 2A Pacific Islands early childhood enrolments by age 1990-1997

\begin{tabular}{|c|c|c|c|c|c|c|c|c|c|}
\hline \multirow{2}{*}{$\begin{array}{l}\text { Age } \\
\text { in } \\
\text { years }\end{array}$} & \multicolumn{8}{|c|}{ Year } & \multirow{2}{*}{$\begin{array}{c}\% \\
\text { Change } \\
1990-97\end{array}$} \\
\hline & 1990 & 1991 & 1992 & 1993 & 1994 & 1995 & 1996 & 1997 & \\
\hline () & 331 & 479 & 447 & 513 & 603 & 691 & 725 & 628 & 90 \\
\hline 1 & 525 & 620 & 700 & 833 & 911 & 884 & 891 & 921 & 75 \\
\hline 2 & 800 & 905 & 1,200 & 1,279 & 1,447 & 1,419 & 1,387 & 1,398 & 75 \\
\hline 3 & 1,707 & 1,990 & 2,292 & 2,688 & 2,710 & 2,776 & 2,874 & 2,867 & 68 \\
\hline 4 & 2,426 & 2.733 & 3,066 & 3,278 & 3,660 & 3,763 & 3,770 & 3,825 & 58 \\
\hline 5 & 222 & 166 & 151 & 209 & 198 & 209 & 181 & 142 & -36 \\
\hline Total & 6,011 & 6,893 & 7,856 & 8,800 & 9,525 & 9,752 & 9,858 & 9,781 & 63 \\
\hline
\end{tabular}

Ministry of Education (1998)

During the period of high immigration, and in recognition of the consequences for tangata whenua of the loss of language, culture, identity, and self-esteem, Pacific Island women decided that action must be taken to ensure the future educational success of their children. Pacific Island women's organisations began early childhood education groups in church halls, garages, homes, spare classrooms at schools and community halls. The establishment of such groups relied almost entirely on community initiative with minimal funding from government and other resources.

The first Pacific Islands pre-school was set up in Tokoroa in 1972. This playgroup is still operating. supported by and through the efforts and dedication of the Cook Islands community. The development of Pacific Island language groups followed the path of Te Kohanga Reo and there early childhood education initiatives have had a huge impact on government policy on education generally. (Cooper and Tangaere, 1994)

During the early to mid 1980s, the growth of early childhood language groups accelerated the A'oga Amata for the Samoans, the Punanga Reo for the Cook Islands and the Niuean. Tongan and Tokelauan groups (Mara, Foliaki, Coxon, 1994).

By 1997 a total of one hundred and eighty-seven Pacific Islands early childhood centres were reported in national statistics (e.g Education Statistics, 1997). Thirty-seven of these 
centres were licensed with the Ministry of Education as childcare centres and one hundred and fifty were registered with the Early Childhood Development Unit (ECDU) as Pacific Island language groups. Table 2B below outlines the number of Pacific Islands language nests from the four main Pacific groups. The numbers of children enrolled in these language nests in 1997 are also reported.

Table 2B Distribution of Pacific Islands Early Childhood Centres

\begin{tabular}{|c|c|c|c|c|c|c|c|}
\hline $\begin{array}{l}\text { Types of } \\
\text { Service }\end{array}$ & $\begin{array}{l}\text { Cook } \\
\text { Islands }\end{array}$ & Niuean & Samoan & Tongan & $\begin{array}{l}\text { Other } \\
\text { P.Is. }\end{array}$ & $\begin{array}{l}\text { Total } \\
\text { Centres }\end{array}$ & $\begin{array}{l}\text { Number } \\
\text { of } \\
\text { Children }\end{array}$ \\
\hline $\begin{array}{l}\text { Licensed } \\
\text { Childcar } \\
\text { e centres }\end{array}$ & 6 & 1 & 26 & 3 & 1 & 37 & 983 \\
\hline $\begin{array}{l}\text { ECDU } \\
\text { Funded } \\
\text { PI } \\
\text { language } \\
\text { groups }\end{array}$ & 33 & 18 & 50 & 37 & 12 & 150 & 3365 \\
\hline Total & 39 & 19 & 76 & 40 & 13 & 187 & 4348 \\
\hline
\end{tabular}

Source : Education Statistics 1997

Proportionally, a third of Pacific Islands children under the age of five are now enrolled in language nests (Education Statistics of New Zealand,1997).

In addition to the language nest movement, a second initiative was proposed by Pacific Allied (Women) Council Inspires Faith in Ideals Concerning All (PACIFICA) and Pacific Islands Polynesian Foundation (PIPEF) in conjunction with the Department of Education and the Bernard Van Leer Foundation of the Netherlands. The proposal recommended that parents be helped in their own homes to participate more fully in their children's learning. using everyday and culturally relevant resources. The first homebased centres were established in 1988 in Auckland, Tokoroa and Wellington. The project is called Anau Ako Pasifika. 
Currently about one hundred and fifty Pacific Islands children are receiving their early childhood education through this arrangement.

The director of Anau Ako Pasifika in a recent paper has commented that the project has been successful in providing an alternative programme in early childhood education for a limited number of Pacific Islands families. In spite of that success, however, it has become evident that parent education as well as language and cultural maintenance, remain urgent needs for a wide spectrum of families (Morgan, 1995).

\subsection{The Development of Aoga Amata}

The term Aoga Amata literally means 'school beginnings'. In name, it evokes the traditional concept of a pastor's school and the important role that a minister's wife carries out in the socialisation of children into the life of the church. As Aoga Amata became incorporated into the general provisions of early childhood education in New Zealand, the curriculum has become increasingly influenced by international perspectives on developmentally and culturally appropriate experiences for infants and young children. The 'beginning' is recognised as lying within the home and extending to the other settings in which children's development is naturally occurring.

The present aim of Aoga Amata movement is to organise and deliver, at the community level, a nationally recognised programme of early childhood education in the Samoan language. It takes account of national curriculum documents. Individual licensed centres are subject to audit by the Education Review Office, but the day to day management of the centre remains the responsibility of a management committee appointed by the parents of the children in the Aoga Amata.

In the Wellington region, the Aoga Amata movement began in 1985 with the opening of the first centre by Mrs Fereni Ete, wife of the minister of the Congregational church in Newtown. As other centres were opened the need to train parents and teachers for service in the Aoga Amata became apparent. Mrs Ete therefore began a series of training programmes. By 1997, over 300 people had graduated from the programmes with nationally recognised qualification in early childhood education. 
For the parents concerned, there are four immediate needs that Aoga Amata seeks to address (Burgess, 1997):

a.

To enable Samoan families to take part with confidence in the early education of their children.

b.

To extend the domains in which children use the Samoan language.

To provide opportunities for Samoan parents to reflect on, and strengthen their roles as first educators of their children.

d. To enable children from families in the wider community, to acquire a Pacific Islands' language through attending an Aoga Amata.

The national curriculum documents (Te Whariki,1996; Taiala mo le gagana Samoa i Niu Sila, 1996) provide criteria against which the quality of early education in the centres is judged.

\section{Involvement of parents and teachers}

Parents work well with children if they are encouraged and trained to participate in children's learning, Sauvao (1996). Parents are obviously a very important influence on the development of children's social skills but so also are teachers, since they work with children in the contexts of larger peer groups which need to function harmoniously if children are to benefit. Observation and assessment skills are a very important part of teacher training, and centre-staffing structures should allow teachers time and space to practise their observation skills. The value of teachers knowing children very well so that they are able to understand and interpret their behaviour within a joint frame of reference cannot be overestimated. The study reinforces the importance of sensitive, skilled and trained staff working with young children in appropriate ratings and small groups within the framework of a carefully thought through curriculum. It is therefore crucial that centres employ well-trained staff, that conditions of work are attractive enough to discourage staff turnover, and staff work together as a team to develop consistent strategies.

The general views of early childhood teachers as reviewed in the study of young children's conflicts by-Katz and McClellan (1991) were that: 
Teachers should intervene as little as possible, so that children can try to solve their own problems, but frequently enough to ensure that no child is falling into a negative recursive cycle. Good decisions concerning when to stand by and when to intervene depend on closely observing interactions and assessing individual children's abilities to resolve conflicts without an adult help, assert and play (Katz \& Mc Clellan, 1991:19).

The continuity of the Samoan language is becoming a major issue of concern for Samoan parents. Parents of Aoga Amata graduates are now beginning to shop around for schools, seeking those that offer bilingual programmes in Samoan and English.

Despite the considerable efforts of the past twenty years, and accepting that there has been an increase in the number of Pacific Island students passing external examinations, entering universities and gaining educational credentials, the area of Pacific Islands education in New Zealand can be described as in crisis. In terms of educational outcomes, Pacific Island groups still show a disproportionate number of students in the lower levels of achievement. Given this state of affairs, the author was motivated to investigate the influence of Samoan language nests on a small sample of children with the hope of gaining evidence of sites of progress.

\subsection{The Transition to School}

Starting school has long been considered a significant milestone in the lives of young children. The child's first day at school marks the commencement of formal learning in contrast to the years prior to school entry which are described as informal learning- a time when children play and learn incidentally (Cullen,1998:30). In commenting on the traditional viewpoint, Cullen has suggested that current perspectives on children's development and learning support a more positive perspective on the notion of preparing children for school. It can become a time where children develop awareness of learning and a measure of control over learning processes.

In a discussion of the transition from pre-school to school, Pratt (1985) challenged the traditional view of a shift in emphasis from the pre-school environment of development through active exploration and experimentation to the school environment of formal teaching set out by adults'. Active exploration and experimentation should always remain an important strand of the school curriculum. 
Dickie (1998) has described the wide variation in the skills and understandings about reading and writing that five-year-old children bring to school from their early childhood literacy experiences. A teacher of new entrants needs to be aware that children may have understandings about reading and writing in their home languages and that these will be a valuable foundation for learning to read and write in English.

The competencies of children with early childhood experiences were highlighted in Cathy Wylie's (1996) study of five year olds in New Zealand. Wylie's research provided some answers to the question regarding children's competencies. She reported that the children in the study showed a wide range of competency level. Most were confident in communication with others. They could play peacefully with their peers, most of the time. They could look after their own dressing and toileting. They could solve problems in their exploration, games, and construction activities. Most were familiar with books, and knew how they should be read - although only a few children were actually reading at this age. Around half could recognise the letters of their own name, and write their name.

Most children were familiar with numbers up to 10. Just under half could recognise a range of different shapes. Around half the children could bounce and catch a ball, and keep their balance while hopping. Many were accurate in using their hands to pick up small objects and lace cards. But very few could cut out shapes accurately, or trace around them

Ecological theory emphasises the importance of transitions because they have a profound effect on immediate contexts of human development (Bronfenbrenner, 1979a). Transitions involve changes in a child's position in the ecological environment as a result of a change in role or setting. For example, new roles are experienced and a wider set of relationships are formed when a child's pre-school settings change into those associated with primary schooling. Bronfenbrenner (1979b) argues that transition can be positive for development. if properly handled. Transitions open up new contexts for learning and new possibilities for development.

In the Kohanga Reo movement, the transition to school is regarded as unproblematic where learning in the two settings is matched and connections are close. Consideration must therefore be given to possible interconnections between the various seltings in which the 
child participates such as the home, Te Kohanga Reo, the school, and the child's immediate community. To achieve this is to enhance the developmental effectiveness of each context.

As stated earlier. Te Kohanga Reo is regarded as one of the most dynamic and innovative educational programmes in the country. Te Kohanga Reo has a distinct Maori pedagogy where practical skills of the child are developed at the social and cognitive level (Kaai, 1990). Children not only learn their Maori side, but more importantly they are prepared for the serious business of doing well in school. Kura Kaupapa M- ori is an inevitable progression and provides the logical continuity from Te Kohanga Reo (Rata, 1989)

The development of Te Kohanga Reo was in part used as a model for the development and establishement of the Aoga Amata. The present study assumes that the transition from Aoga Amata to primary school, is part of a wider issue of continuity between socialization and education processes in the home and the opportunity for expanding development that can occur through early childhood education services, schooling, and in various church and community contexts. The study also assumes that continuity is a two-way process that should enhance all contexts that children find themselves in.

\section{Language Maintenance}

Most language competencies develop before school, including the pragmatic aspects of language (how and when and for what purposes language is used). However, particular forms of socialization may be well or poorly matched with standard classroom processes (Erickson. 1984; Heath, 1983.).

Heath in her studies of families in the United States, claims that rescarchers ank their students questions which have answers pre-specified in the minds of the teachers. Students then respond and teachers provide feedback usually in the form of an evaluation. Such classroom procedures are well matched with the experiences that some students bring to school, and poorly matched with the expertise of other students. Like Bronfenbrenner, she argues that the degree to which classrooms match the skills students have acequired. and the degree to which families are involved in schooling will influence language development. One might ask the question what is the result for children if the settings are mismatched as in the specific case of Aoga Amata children? 
According to Roberts (1990), language maintenance and shift are often referred to in the one phrase, as though they are necessarily interrelated. This viewpoint, however, seems to preclude the development of two first languages in childhood, the goal of most bilingual programmes. Whether or not equivalent proficiency in a heritage language and English can he achieved in New Zealand settings is very much an open question. Furthermore, Roberts hats pointed out that no one group of people speaking a given language ever maintains that language in the sense of maintaining it unchanged.

Verivaki (1990) studied language maintenance within the Greek community in Wellington. In the contexts that she studied, language shift seemed inevitable and appeared an outcome of the successful integration of an immigrant group into a dominant host culture.

Language maintenance and language shift are the long-term, collective results of language choice (Fasold, 1984). Language maintenance occurs when a group of people choose to continue to use the language traditionally associated with their group and for purposes that promote solidarity. The decision to use any particular language may be conscious or unconscious. In immigrant communities, the first generation may make an unconscious decision to continue using the traditional language while this decision may be a conscious one for subsequent generations (Verivaki. 1990).

In the New Zealand context, children born in Aotearoa of parents who were both born overseas are called the second generation while children born of New Zealand born parents are called the third generation.

If language shift is occurring within the Samoan community, the first gencration of Samoan immigrants in New Zealand still use the Samoan language fluently while the second and third generations have increasing difficulties in maintaining native speaking proficiency. Evidence of language shift has been noticed in the Chinese community (Ngan, 1987). By the third or fourth generation the heritage dialects of Chinese have all but been lost. The Dutch community in Auckland has shown a near complete shift to English by the third generation (Kroefs, 1977). The major factor working against Dutch retention was the lack of emphasis placed on aspects of Dutch culture by most of the families interviewed. The shift 10 the use of English in the home was often initiated hy the parents lhrough the 
actions of their children, who came home speaking English from school, brought nonDutch friends home from school and who married non-Dutch speakers.

A great variety of factors are involved in accounting for patterns of language maintenance and shift. Giles et al (1977) systemised these factors into a model of ethnolinguistic vitality, a term that refers to factors that "make a group behave as a distinctive and active collective entity in intergroup situations... the more vitality a linguistic group has, the more likely it will survive and thrive as a collective entity in an intergroup context". The more vitality the group has, the more likely it will retain the language traditionally associated with that group.

Giles et al (1977) measured ethnolinguistic vitality by using three different groups of factors, each of which can influence language maintenance and shift:

1) Group status (economic, social, socio-historical and language status)

2) Group characteristics ( size of the group, geographical distribution)

3) Institutional support (social organisation, mass media, education, etc).

However. Verivaki (1990) commented that it is not possible to say whether these factors work for or against language maintenance or shift. For some groups, certain factors will work positively towards language maintenance, yet for other groups, the same factors may not be important, or they may even work against language maintenance and towards language shift. Clyne (1982) found, for example, that population size of a group did not correlate consistently with degree of language maintenance. In South Australia, this factor seemed to work in three different ways for three different groups: for Germans. it corresponded with language maintenance, for Greeks, with language shift, and for the Maltese, it worked both for and against language shift.

The main factor responsible for language shift in the Greek community in Australia is intermarriage, and even here there are different likelihood of shift relating to gender and education. Tamis (1985) found that a greater proportion of Greek women than men maintain Greek in an inter-ethnic marriage. while it was mainly the men, and the better educated, that married outside the community, and tended towards language shift.

The study by Verivaki (1990) showed that the Greek community in Wellington. where a Greek school had been established for over 50 years, still spoke Greek in about $80 \%$ of 
households for at least half the time.

In summary, it would appear that language maintenance has a somewhat higher value for the Greek community in New Zealand than for the Chinese. Language is important and although it is not seen as a defining characteristic of "Greekness" it is viewed as an element of high additive value in the construction of a Greek identity (Roberts, 1990).

The factor of intermarriage also affects Samoan language maintenance in New Zealand. Intermarriage facilitates language maintenance while out-marriages lead to language shift, especially where the mother is not a native speaker of Samoan. Fairbairn-Dunlop's (1984) found that $78 \%$ of the children in her sample of 40 Wellington Samoan families spoke Samoan fluently, simply because the parents were fluent in Samoan and used that language at home and in church affiliations.

Jamieson (1980), in studying immigrant communities in Newtown Wellington, made two important points: (i) In order to discover how successfully the ethnic language is being passed on to the children, it proved sufficient simply to ask the parents how well their children spoke the language; and (ii) that in order to gauge attitudes to language maintenance it was sufficient to ask the parents if they wanted their children to be able to speak the language when they were adults.

Silver (1982) maintained that "Language is obviously related to thinking. There is evidence that language and thought develop independently, that language follows rather than precedes logical thinking, and that even though language expands and facilitates thought, high level thinking can and does proceed without it". A recurrent theme in the writing of Piaget is that logical thinking exists before the appearance of language, during the middle of the second year (ibid).

Millions of children in the world are acquiring one language as their 'mother tongue' and subsequently learning another, either informally as they come into contact with children and adults who speak it. or formally as they receive second language instruction in the early years of schooling (Saville-Troike, 1982). This "Language acquisition is greatly affected by_social circumstances" Saville-Troike (1982:3). Having said that, families and communities have a measure of control over what those social circumstances are. Families can include grandparents, children can be enrolled in language nests, churches can use 
heritage language policies that can give a role to community languages in education. However, in predominantly monolingual countries, children from heritage language and cultural hackgrounds are obliged to learn the rules of the dominant culture if they are to 'succeed" according to its value (ibid).

The process of adding a second set of rules for behaviour is called acculturation. One possible result of acculturation is assimilation - the loss of the native culture or the merger of cultures until they are indistinguishable. Another possible result is the selective maintenance and use of both cultural systems namely hiculturalism. However the complexity of the issues raised by biculturalism are rarely acknowledged.

I believe, through my experiences as a teacher and mother, that the learning of culture, like the learning of language, begins with children's first experiences within the family and community and within the environment in which they live. By the time children begin their formal education, they have already internalised many of the basic values and beliefs of their native culture, learned the rules of behaviour which are considered appropriate for their role in the community, and established the procedures for continued socialization. They have learned how to learn.

\section{The rote of Samoan in education}

There have been three major studies on the role of the Samoan language in the education of children in New Zealand (Fairbairn-Dunlop. 1984: Lameta-Tuluga, 1995: and Masina, 1997). Fairbairn-Dunlop studied the factors perceived by families an facilitating or constraining Samoan language maintenance. She isolated the critical role of the extended family, the church, and children's visits to Samoa, in providing the opportunities for the language to develop across a wide range of functions. She drew attention to the potentially subtractive influence of English only classrooms when the bilingualism of children was not acknowledged. Community attitudes were also imnortant. She warned algainst the complacency of those Samoan families who helieved that they did not reyuire the sehool to be directly involved in language maintenance.

Lameta-Tufuga (1995) examined the effect of using Samoan as the language of discussion when students were engaged in tasks associated with their academic lcarning. She showed 
that there were considerable benefits to be had in a variety of subject and topic areas when input in English was followed by group opportunities to talk in Samoan. Students who negotiated tasks in Samoan improved their knowledge of low frequency vocabulary, recalled basic information more accurately, and were able to write better constructed answers than matched students who registered the Samoan tasks in English. An important part of her work lay in showing that the benefits of using Samoan in group discussion were reflected in English language performance. Although the group talk was in Samoan, the test performance was in English.

Masina (1997) has outlined the emergence of Samoan as a language of learning in formal education New Zealand. He traced the development of the Aoga Amata movement, the origins of the Taiala, and the policy shift in the New Zealand Curriculum framework. He drew attention to the policy vacuum in primary schools. The Aoga Amata movement had influenced early childhood education; the teachers of Samoan at universities had influenced the courses of study available in secondary education, but primary schools had no identifiable programmes, apart from an occasional bilingual initiative in junior classes. Clearly, the Aoga Amata movement has the potentiality to influence the junior school if not the middle school. The Taiala did not grasp the opportunity that was there to develop an exciting relevant curriculum at that level. In my view, there is nothing in the Taiala to excite or challenge a primary school teacher to bring the Samoan language in to the life of a child's education. In concentrating on the needs of new speakers of Samoan it overlooked the needs of children who were already proficient users of the language.

The Aoga Amata movement is producing confident speakers of Samoan who need a different kind of programme to that envisaged by the Taiala. Space needs to be found for Samoan as a language of learning, in partnership with English, if continuity is to be achieved in the education of recent graduates from the Aoga Amata. The present study will therefore look at the transition practices experienced by Aoga Amata graduates, as well as the factors perceived to facilitating or constraining the continuity of their language education. 


\section{Samoan research}

What does it actually mean to conduct research from a Samoan perspective? In one sense, it provides a cultural lens through which the educational development of children can be viewed. The description of personal and cultural identity can be couched in alofa, aiga, faraloalo. fait-le -agaga. fai-le-nutu. genealogy, and values embedded in the pedagogical principles of the Aoga Amata. This is similar to principles of Te Kohanga Reo where young Maori children acquire a sense of cultural identity couched in aroha, whanaunga tanga, manaaki, wairua, turanga waewae and whakapapa (Kaai, 1990:69).

In a second sense, research from a Samoan perspective places the education of Samoan children at the centre of the research stage and asks how services are contributing to the development of the child (not how the child is adapting to the services).

\subsection{Summary}

Most New Zealand children now attend some kind of early childhood education before they go to school. Overseas research has shown that good quality early childhood education has a bearing on children's achievement, and on their long-term education employment. and social participation. It is important that New Zealand has similar research, following children through from experiences in early childhood education, until they leave school.

The experience of attending an Aoga Amata secures a child's identity within the Samoan strand in the child's heritage. However, the path to full bilingualism and biculturalism is not without its complexities. The transition to school may not be straight forward. but at least it is a manageable opportunity to enhance a child's development. given appropriate conditions and the will to put the child at the centre of educational experiences.

The review of the literature suggests major implications for schools and research. One implication rests with the disparity so eloquently highlighted by the Waitangi Tribunal in its report..between the official line and actual practice. In New Zealand the public outcry is one of a society based on equality of opportunity. That is the right of all people 10 advance socially. economically and politically, according to their specific lalents and abilities 
without impediment to this advancement'. The reality on the ground is very different. For a change, schools will have to provide programmes based on client needs if they are to survive. The present study is a response to the need for research on the transition of Aoga Amata children to primary school. Details of the design and methology utilised in this investigation are contained in the next chapter. 


\title{
CHAPTER THREE
}

\section{RESEARCH DESIGN AND METHODOLOGY}

\author{
E lele le toloa a e ma'au i le vai \\ A wild duck is in flight searching for the pond. \\ Samoans overseas always look back on their roots or \\ ancestors for cultural advice and directions.
}

\subsection{Introduction}

The issues discussed in the literature review together with the problems and rationale presented in chapter one determined the research questions which guided the present study. The main aims of the research were to investigate the following: (i) the strategies used by parents, teachers and principals to cope with the transition of Aoga Amata children to school; (ii) the impact of the transition on children; (iii) the perceptions of parents about Aoga Amata programmes; (iv) the perceptions of teachers about the transition to primary school; and (v) the factors thought by stakeholders to be contributing to the maintenance of the Samoan language in school.

The study used structured interviews to gather information from those participating in the study. The interview questions were developed so that information relevant to answering the research questions could be elicited from the various stakeholders in the transition process. In developing the data gathering procedures, attention was paid to the cultural context in which people were being asked to supply information. Details of the research decision are presented in section 3.2 Detailed descriptions of each of the phases of the research designed are provided in sections 3.3 to 3.7. This followed by a discussion of the problems and difficulties encountered in the research, in Section 3.8. Finally, Section 3.9 summarises the main points of discussions in this chapter. 


\subsection{Research Design}

The research was designed and carried out in five phases:

Phase 1: A literature search in order to identify potential issues in the continuity of education experienced by Pacific Islands children in New Zealand (section 3.3).

Phase 2: The development and screening of a pool of interview questions (section 3.4)

Phase 3: The selection and interview of participants in the study (section 3.5)

Phase 4: The analysis of the responses gathered from parents, children, teachers, and principals (section 3.6).

Phase 5: The writing of the research (section 3.7)

The sequencing of the different phases of the present study are outlined in Table 3A below.

Table 3A Sequencing of the phases of the study

\begin{tabular}{|l|ll|}
\hline Year & \multicolumn{1}{|c|}{ Phases of the study } \\
\hline $1996-1997$ & Phase 1: & Literature search \\
& Phase 2: & Development of interview schedule \\
& Phase 3: & Selection \& interview of the participants- Main study \\
\hline 1998 & Phase 4: & Data Analysis \\
& Phase 5: & Writing of the research \\
\hline
\end{tabular}

\subsection{Phase 1: Literature Search}

My aim at this stage in the study was to discover effective ways to identify research that had been conducted on the transition from early childhood centres to primary schools. I wanted to access these studies, integrate their findings, and produce a framework that would allow me to develop research questions and a relevant interview schedule for the topic of my study.

I used five libraries in the Wellington region: Victoria University (VUW) library; the New Zealand Council for Educational Research (NZCER) library; the Wellington Multicultural Resource Centre library; The National library; the Wellington Public Library (including the Newtown and Porirua Branches), and the Wellington College of Education library. I used the VUW library as a starting point. Using the computer catalogue, I was able to develop a 
set of search categories: early childhood education, transition to primary schools, and language maintenance.

As I explored the references listed under those categories, I developed a series of subheadings, and a "topic map" of the area. For example, transition to primary school became one facet of achieving continuity in a child's education. This insight opened up for me the possibility of examining other kinds of transitions that Pacific Islands' children might be experiencing at any moment in time. It also pointed my search in the direction of transitions experienced by children in Te Kohanga Reo and in other parts of the world.

In visiting other libraries, I found myself adding to the map, filling in gaps in my understanding of the topic, and confirming the lack of published studies that focus on the kind of bilingual context that I was interested in. I could not find any study that had examined the perceptions of Pacific Islands families or of teachers as children moved from Pacific Islands' early childhood education centres to primary schools. This further highlighted the need to conduct study in this area of education.

\subsection{Phase Two: Development of Interview Schedules}

Four structured interviews were designed for parents, teachers, principals, and children respectively. In developing the interview schedules, I began by carefully defining the kind of information I needed to gather from the various stakeholders. Using the medium of English, I then developed a pool of questions designed to elicit the relevant information. A research student in the $\mathrm{PhD}$ programme examined the content and form of the questions, using the criteria of research relevance, clarity, and potential informativeness. My supervisor also checked the questions against the aims of the study, and by using intuitions as to how inquiry should proceed in Pacific Islands contexts. At this stage, the sequencing of the questions within the four schedules was established, as were the techniques I would use to clarify responses, while remaining warm and friendly yet neutral on the topic. The questions were then reformatted into Samoan, so that two versions of the interview questions were available. (See Appendix A1). 
In general, the questions were framed in such a way to yield substantive information. Where Yes/No questions were used, they were immediately followed by a "why" question requiring further details. A typical sequence appears in the Table 3B.

Table 3B An example of question sequence

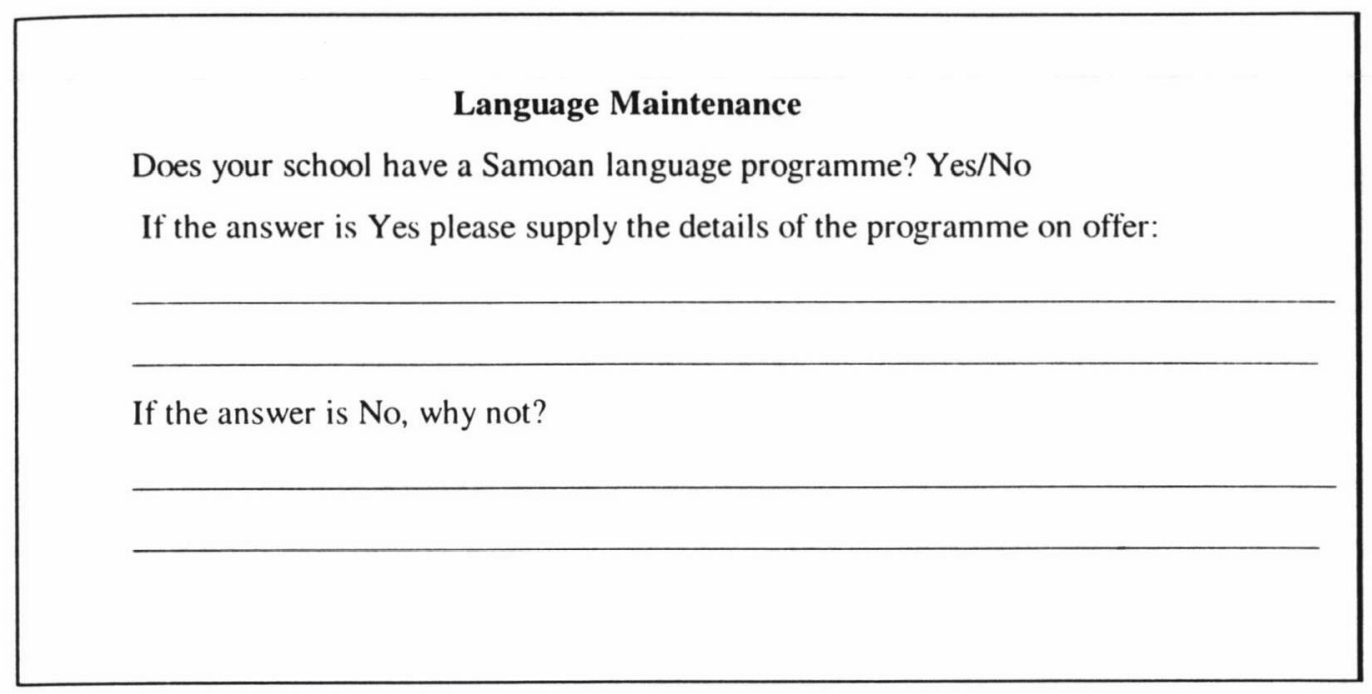

Questions for parents and children were available in Samoan. The questions for teachers and principals remained in English. Thus, the language of discussion was open, enabling participants to respond comfortably in the language in which the particular point was likely to be enćoded. Details of the interview questions for principals and teachers are presented in Appendix A3 and A4, respectively.

\section{5 Phase Three: - Main Study}

\section{Selection of participants}

Through the community network, I approached the teachers and supervisors of Aoga Amata in four districts in the Wellington region (Naenae, Porirua, Newtown, Strathmore). I asked them to supply the names of recent graduates and the names of the primary schools that had received them. A list of fourteen schools was compiled by this method. Each school was approached with a view to obtaining consent to interview children who had attended an-Aoga Amata for at least one year during the period 1989-1995. 
Through negotiation with the parents, principals, and teachers in the fourteen schools, twenty children were chosen. Table $3 \mathrm{C}$ contains a summary of information pertaining to the 20 children who participated in this study.

Table 3C Summary of children selected for the study

\begin{tabular}{|c|c|c|c|}
\hline Children's Code & Age & Gender & Ethnicity \\
\hline 1 & 6 & $\mathrm{~F}$ & Samoan \\
\hline 2 & 11 & $\mathrm{~F}$ & Samoan \\
\hline 3 & 6 & $M$ & Samoan/Maori \\
\hline 4 & 9 & $\mathrm{~F}$ & Samoan \\
\hline $5^{*}$ & 9 & $\mathrm{~F}$ & Samoan \\
\hline 6* & 8 & $\mathrm{~F}$ & Samoan \\
\hline 7 & 10 & $\mathrm{~F}$ & Samoan \\
\hline 8 & 10 & M & Samoan \\
\hline 9 & 12 & $\mathrm{~F}$ & Samoan \\
\hline 10 & 7 & M & Samoan \\
\hline 11 & 7 & $\mathrm{~F}$ & Samoan \\
\hline 12 & 7 & $\mathrm{~F}$ & Samoan \\
\hline $13 *$ & 6 & M & Samoan \\
\hline 14 & 8 & M & Samoan \\
\hline $15 *$ & 6 & $\mathrm{~F}$ & Samoan \\
\hline $16^{*}$ & 11 & $\mathrm{~F}$ & Samoan \\
\hline 17 & 6 & $\mathrm{~F}$ & Samoan \\
\hline 18 & 6 & M & Samoan \\
\hline 19 & 6 & $\mathrm{~F}$ & Samoan \\
\hline $20 *$ & 6 & $M$ & Samoan \\
\hline
\end{tabular}

Children selected for the six case studies are marked with an * in the above table.

The children were selected so as to represent in a balanced way the range of transitional situations in the respective school districts. For example; five children were selected from a school that provided a bilingual programme, five students who had received support from a Samoan speaking person within an English only programme, five students who had received some peer support from older Samoan speaking children, and five students who had received no- special consideration. From the choice of children, the parents. teachers, and school principals were identified. In all, the sample included 20 children, 39 parents, 14 
teachers and 14 principals. A summary of the types of schools used in the study appears in Table 3D, below.

Table 3D Summary of the five types of schools used in the study

\begin{tabular}{|c|c|c|}
\hline $\begin{array}{c}\text { School } \\
\text { Type }\end{array}$ & \multicolumn{1}{|c|}{ Nature of Samoan Language Provision } & $\begin{array}{c}\text { Number(s) } \\
\text { of Schools }\end{array}$ \\
\hline I & Offers a bilingual programme for the first two years at school (JI,J2) & I \\
II & $\begin{array}{l}\text { In class support is provided by either a Samoan speaking teacher, or is available } \\
\text { from a Samoan member of the non-teaching staff on request. }\end{array}$ & 3 \\
III & $\begin{array}{l}\text { Peer support is used by inviting older children and/or family members to stay } \\
\text { with the Aoga Amata graduate. Alternatively, cultural activities are integrated } \\
\text { into the curriculum in different ways (e.g. through Polynesian cultural groups) }\end{array}$ & 5 \\
IV & $\begin{array}{l}\text { No special provision is made or consideration given to Aoga Amata graduates. } \\
5\end{array}$ & 5 \\
\hline
\end{tabular}

A sub-sample of six children was selected for case study purposes. The children were chosen because of the unique and special circumstances that each represented. (See chapter 5). I wanted to look at the progress and achievement made by two children who attended primary schools which provided Samoan language (Type I and Type III). In contrast, I chose two further children, one male and one female, who attended primary schools which did not include Samoan language in their school curriculum (Type II). The remaining two children attended primary schools which had no provision for the Samoan language (Type IV) but their individual progresses showed very significant outcomes in the maintenance of the Samoan language. One of these two children through the great effort of the extended families and church communities was able to maintain her Samoan language with great fluency.

The procedures for gaining consent and selecting the sample were carried out using culturally appropriate communication processes in addition to the ethical values required by the Human Ethics Committee at Victoria University of Wellington. Face-to-face interaction was used with native speakers of Samoan prior to presenting letters of intent and consent. 
Observance of faafeiloaiga fai Samoa (cultural greetings), faialoalo (respect and supply of food), faamalie ona o ni itu e faalavelavea ai le taimi o le suesuega (acknowledgement of intrusion) and lauga faamavae/faafetai (farewell and appreciation speeches) were built into the meeting procedures with the various informants/participants. The ethical standards of informed consent and confidentiality were sought and assured using communication pragmatics associated with the ethnicity of the informants.

\section{Making contacts with parents}

Appropriate Samoan protocols were adhered to when interviewing parents. In districts where the parents were not well known by the researcher, a group meeting was held at one of the Aoga Amata centres in the area. The invitation to attend the meeting was conveyed by word of mouth via the supervisor of the Aoga Amata who knew the parents in the area.

The purpose of the group meeting was to inform the parents about the research and to obtain their consent. During the meeting, the parents expressed their interest in the project, their views of its importance, and their willingness to be involved. The meeting concluded with the signing of consent forms. The consensus - making forces at work in such a meeting led to all the issues being thoroughly explored until a level of total satisfaction with the project was reached. Individual consent thus became a by-product of the group consent tacitly expressed through the ebb and flow of discussion. Straight after the group meeting, a few of the parents were interviewed individually and the rest of the parent interviews took place in their homes as they preferred. A copy of the consent form for parents is presented in Appendix B1.

In districts where the families were known to me through church, family and community connections. a different procedure was followed. Each family was visited after the initial telephone approach. During the ensuring visit, consent was obtained using Samoan protocol. Following the expression of consent, the interviews took place. The meetings occurred in homes at times when family members and children were available. The meetings usually lasted between one and a half or two hours. Details of interview questions for parents and children are provided in Appendices A1 and A2. 


\section{Making contacts with children, teachers and principals}

Interview meetings were also held at the receiving schools. I contacted the principals. teachers, and children after seeking the approval of the parents. A copy of the consent form for teachers and principals is contained in Appendix B2. Again the purpose of the study and the procedures were discussed and agreed to by the participants, including the children. Interviews following the formal collection of consent at times scheduled by the school. The following Table $3 \mathrm{E}$ outlines the order of the 14 school scheduled interviews:

Table 3E Order of interviews carried out in schools.

\begin{tabular}{|c|c|}
\hline Order of school interviews & Participants \\
\hline First & Individual children \\
Second & Individual teachers \\
Third & Individual principals \\
\hline
\end{tabular}

This order was the choice of the principals as they were usually busy in the mornings, and it was also appropriate to hold interviews for the children in the morning while their minds were lively and fresh. In cases where the children were not in school during scheduled interview times, their interviews were conducted at home with the approval of the parents, or a researcher's second visit would be rearranged with the principal and the teacher to interview children who preferred to be interviewed in school.

The language of discussion was Samoan for speakers of Samoan, and English where nonSamoan speakers were present. Documents were prepared in both Samoan and English with the intention that participants choose the language they preferred to use in understanding the study. 


\section{Interviews with parents}

In conducting the interviews with parents, cultural values were observed. As a Samoan matai, I felt comfortable in handling the cultural situation with the parents who are matai. This is very important when doing research in the Samoan community. Tupuola (1993) in her study of Samoan adolescence, emphasised the imperative, cultural sensitive approaches that ought to be addressed in carrying out researches concerning ethnic groups. An issue which was at times disregarded when some of the non-Pacific Islands researchers undertook research projects both overseas and in these communities within New Zealand. Masina (1997) supported and addressed this issue as well in his study about the Emergence of Samoan Language in New Zealand.

The present study on the whole was carried out with deep, genuine and absolute consideration of these cultural values. The meeting would begin with the exchange of greetings including the cultural honorific acknowledgement of the family and its chiefly titles. For example, I was greeted with the address of my matai title and the honorific of my village and family title by the parents and grandparents who knew me. I returned the greetings in the similar manner acknowledging the parent's title and their village honorific as well. Face-toface casual discussion of the families tupuaga (genealogy) and positive talk about the child and the family's role in early childhood education would then proceed the actual interview. The interview questions were asked in a conversational rather than an inquisitorial manner. Questions likely to raise controversial issues were raised later, rather than earlier during the interview. frequently while food was being shared. On occasions. respect suggested that the interview be suspended for family events that arose during the scheduled time.

The placement of people during the interview observed the cultural preference of using the mat. For example, in one family the grandparent (matai/titled father) greeted me while sitting on the mat. This was one cultural ways of respecting visitors. In return, I too sat on the mat and interacted with both the parents and grandparents, although they insisted that I use the chair. Leave-taking observed the values of lauga fatetaiffaumavae (thank you and farewell speeches) and fesoasoani (help/obligation). 


\section{Interviews with children}

I conducted most of the children's interviews in the schools, and as previously mentioned, due to family arrangement for some children, parents preferred to hold their interviews with their child together at home on their scheduled day. therefore these were carried out as requested. Usually I asked the younger children if they wanted to have someone with them during their interviews. This way I would not appear to frighten or make the child feel uncomfortable. Of the twenty children, only one six year old asked to have the teacher stay with her during the beginning of the interview. The teacher stayed for 10 minutes then departed when the child comfortably responded to the performance tasks. The other nineteen children felt at ease throughout the interactions. They particularly enjoyed doing the activities on the performance task sheet.

During the interview with the children, each child was asked to do three mathematical tasks in order to establish the child's proficiencies in spoken Samoan and their acquisition of mathematical concepts. The tasks were: (1) counting objects that were displayed in front of the child, (2) sorting objects in order of size, and (3) responding to instructions that required objects to be placed in particular positions. The positional words used in the instructions were : laga(on) totonu (in), fafo (out), i luma (in front of), and i tua (behind).

A number of language performance tasks were also used through asking the children to carry out simple instructions. (See Appendix C). The instructions required children to move to particular positions in the room, place objects in certain locations, identify colours, talk about their families, and read from their favourite books. As the child responded to the above tasks, I recorded qualitative assessments of their level of spoken Samoan. Where children experienced obvious difficulty in using Samoan, the tasks were completed in English.

\section{Recording interview data}

The interviews were not tape recorded due to the prefierence expressed hy the participants. Instead, I listened and participated as neutrally ats possible in the conversation thatl resulted from asking the specific questions. As the informant talked. the actual words used were 
recorded on the interview form. At the conclusion of the interview, I read back the information and sought agreement from the informant that an accurate record had been kept. During this time, the informant was encouraged to clarify, extend, or elaborate responses to the more open questions. It was during this period of the interview that considerable interaction took place between the informants and myself. Table $3 \mathrm{~F}$ below shows the sequential order of the interview procedures.

\section{Table 3F Sequential order of operations within the interview procedure}

\begin{tabular}{|c|c|}
\hline Steps & Interview and data recording procedures \\
\hline 1 & $\begin{array}{l}\text { Cultural exchanges of greetings and brief informal casual conversation with parents and } \\
\text { grandparents. }\end{array}$ \\
\hline 2 & Researcher asks the questions \\
\hline 3 & Researcher writes answers and probes for further clarifications. \\
\hline 4 & Researcher reads back answers to the informants to check for accurate record. \\
\hline 5 & Informants clarify, extends answers and elaborates on unclear information. \\
\hline 6 & Researcher edits added information \\
\hline 7 & Researcher re-reads edited information to the informants for tinal check of data record. \\
\hline 8 & $\begin{array}{l}\text { Conclusion of interview includes; Cultural leave-taking and speeches of appreciation and } \\
\text { farewell. }\end{array}$ \\
\hline
\end{tabular}

A slight change to the above interview procedures was made for the European principals, teachers, and children. Generally the data recording method for the study is similar throughout, but different approaches were used in the cultural aspect when interviewing Samoan participants. Each of the four sample groups had a different interview questionnaire which was carefully designed to collect data as required to respond to the key research questions.

\subsection{Phase 4: Data Analysis}

The questions in the interview schedule were sorted according to the research question they were intended to inform. The responses to each interview question were then transcribed onto a data-sorting card so that the range of responses could be examined, as well as 
common themes and trends in the data. An example of a data-sorting card is given in Table $3 \mathrm{G}$ below.

During the interview, parents were asked why they chose to send their child to an Aoga Amata (contributing to research question 3). Only the responses of ten parents have been transferred onto the card below. Responses that are similar have been grouped together to show the trends in the data.

Table 3G Data sorting card

\section{Data sorting card}

\section{Research question:}

What are the parents' perceptions of Aoga Amata programmes and the management of the transition?

Relevant interview questions: 1 - 8 .

Interview question 1: Why did you send your child to Aoga Amata?

Responses to the question:

- To preserve the Samoan ways

- To maintain the Samoan language

- To learn the Samoan respect

- To be aware of Samoan culture

- To support the church

- It is ctheaper than other early childhood centres

It is handy to home

Grandma teaches there

- I teach there

- To learn his father's heritage language and my son also goes to Kindergarten in the afternoon because it suits our family situation, as we both work and it is easier for us to pick him up after kindergarten.

When the data sorting cards were completed, I returned to each research question and answered it by describing the range and tendencies from the responses. At this stage, key responses were identified as potential quotations to support trends in the data.

Throughout the data sorting process. I kept in mind any special circunstances that might have influenced an informant's response. For example, one family preferred to send their child to both an Aoga Amata and a kindergarten. However, the parents came from two different language backgrounds (Samoan and Maori) and English was the dominant language 
of the home. A decision was also made at this stage as to what interesting fiatures were present in the data both theoretically and from the perspective of practice. In the above example, diglossia (the use of two languages in different situations) was identified as an issue, solved pragmatically by the attendance of the child at two different early childhood education centres. In actual fact, the practice was also expedient for the family concerned as it fitted better their work arrangements.

\subsection{Phase 5: Writing of the Research}

This is the difficult phase which I could not figure out for a long time which chapter to start off with. Anyway, after consulting with my thesis supervisor, I came to a decision that I would carry out the writing process in the following order which I found comfortable and it suited my busy commitment schedule.
a) Chapter Two: Literature review
b) Chapter One: Introduction
c) Chapter Four: Results
d) Chapter Five: Case Studies
e) Chapter Three: Methodology
f) Chapter Six: Conclusion

This was a time consuming phase. in which various drafts of each chapter were submitted to my supervisor for comments. Ill-health and other unforseen circumstances also delayed the writing-up phase.

\subsection{Problems and Difficulties}

The qualitien of the interview schedules were examined by checking the validity of the questions and recording the problems and difficulties encountered in carrying wut the survey.

The face vatidity of the questions in the interview schedule was assisted by using Samoan as the language for the interview, so that common understandings could be assured. For 
example, the term mafuaaga (a reason) has an easily agreed meaning between speakers of Samoan that might not be the case if the English word had been used. The validity of the interview questions was also examined by justifying how responses to the questions might contribute to answers to the research questions. For example, the reason given for sending children (1) an Aoga Amata provide a window on the parents perceptions of the Aoga Amata service in their district.

The particular difficulties encountered in interviewing parents could be classified as issues of time, availability, and circumstance. The time taken to conduct the interview in a culturally appropriate manner placed some stress on family organisation. For example, interviews were interrupted by phone calls, unexpected visitors calling on the family, and routines of childcare. Sometimes there were difficulties in finding an appropriate time where both parents were available due to work and church commitments. The use of informal social networks to contact parents sometimes led to delays in establishing meetings because phone numbers and addresses had changed. Community events, such as bereavement, sickness, and family celebrations also affected the times at which families could commit themselves to meetings.

School visits were time-tabled around the school calendar. On occasions some teachers and some principals preferred to fill the questionnaire form rather than take part in a personal interview, because of school commitments. When the latter choice was exercised, the questionnaires were not always completed in full. In such circumstances, a follow-up visit was undertaken, or a phone call was made to clarify responses or to complete the questionnaire.

Lack of resources within the university library about the topic was another problem which led me to have various costly trips to other institutional libraries, because of long distances.

During the writing process I found myself planted on the computer seat for hours and this resulted in having regular hand and arm pains which I ended up paying regular visits to the medical doctor for treatment of swollen and aching hands. This was a costly experience for me while undertaking this project. 
As a part time student, church elder, family leader and community person, I found the pressure of full time employment, community, family and church commitment hindered the productivity progress of the writing process. In addition, during some stages of the writing process, the heavy work load carried out by my supervisor which involved attending overseas conferences and national workshops, together with overseals trips for parents' illnesses, resulted in me having a relieving supervisor who had different approaches and methodologies to the topic, carry out the supervisory role. This resulted in me having to rewrite several chapters to suit the advice given by the temporary supervisor. On the return of the main supervisor, several changes had to be made to the drafts and this of course was one of the factors which contributed to the delays in the completion of the whole thesis.

\subsection{Summary}

Obtaining information in cross-cultural contexts provides a challenge to a researcher. Information from Pacific Islands informants and Samoans in the context of this study must be gathered in culturally sensitive ways and in contexts that enable the frank expression of views to emerge. The language of discussion, and the symbolism used, become crucial issues in constructing perceptions of past events. The experiences of the transition to school were being recollected and reflected upon a year or more after they had occurred. The cultural match between the parents and the researcher therefore become important in recalling the events and their perceived effect on children. The results of the investigation are reported and discussed in the next two chapters. 


\title{
CHAPTER FOUR
}

\author{
RESULTS
}

\section{Ia to maia lau o le sailiiliga \\ Reveal the outcome of your search}

\subsection{Introduction}

The transition to primary school by children who have attended Aoga Amata was studied through the eyes of the children and parents, as well as through the eyes of the teachers and principals of the receiving primary schools. Information was also gathered on the continuity between the Aoga Amata and the school in terms of the curriculum, language policies, and the factors that might be encouraging or constraining language maintenance.

The responses to questionnaires were collated and analysed so as to provide an information base on which the research questions could be answered. It is important to acknowledge that the answers provided refer to the points of view of the people sampled and refer to the situation as experienced by the participants across the years 1985 - 1995 in the Aoga Amata movement, and between 1990 - 1996 in the receiving primary schools.

The chapter focuses on the perceptions of thirty-nine parents, twenty children, fourteen teachers and fourteen principals interviewed from within the Wellington area namely; Lower Hutt, Porirua and Wellington. Coping with the Transition is described in section 4.2 while the Aoga Amata Programmes is outlined in section 4.3. Information about the transition to primary school is explained in section 4.4 whereas section 4.5 presents the summary of the chapter. 


\subsection{Coping with the Transition}

The first research question addressed in the results is:

How do Samoan speaking children from Aoga Amata cope with the transition to primary schools?

Two sources of information were used to answer this question: Information from parents and information from the receiving teachers. The parents were asked to recall the affective responses of their child during the transition, especially to a change of language where this occurred. Teachers were asked to recall their concerns and how they responded to those concerns. They were also asked to recall how the child coped with changes in the language of instruction.

\section{Affective responses from the parents}

The thirty-nine parents had had the experience of at least one of their children making the transition from Aoga Amata to school. Their recollection of the transitional experience varied according to the language policy of the school. Where the receiving teacher was Samoan, and where Samoan was used as the language of the classroom, positive recollections of the experience were expressed. For instance, one parent reported:

Na fiafia tele le alii i le aoga ona e Samoa lona faiaoga, toe iai le vasega faa Samoa a le aoga na avea ma sooga o lona aoaoina $i$ le gagana Samoa mai ma lana Aoga Amata. E lei faigata ia te ia le suiga fou o lana aoga
He enjoyed school because he had a Samoan teacher and he was also in a Samoan class which linked his Aoga Amata experience. He did not find it difficult to settle in his new school.

In contrast, children who were received into an English only class were remembered as being diffident, anxious, withdrawn, uncomfortable, and slow to respond to the class programme. As one parent said: 
Faigata ona malamalama ona e le masani ai ona faalogo pe tautala faaperetania. E fou foi $i$ lana faalogo le tele o le gaosa o le gagana Peretania. Sa amata mai lava Puipuiau i le gagana Samoa ma tautala ai lava. Sa faigata foi ia te au ona ou malamalama ma fesoasoani i ana galuega e aumai $i$ le fale ona e le iloa faamatala mai. $O$ lona le iloa lelei o le Igilisi, na aafia ai lona agai i luma $i$ se taimi umi pe tusa ma le tausaga.
Puipuiau found it difficult to understand English as she was not used to listening to it being spoken. The different concepts of English language were all new to her. She was brought up in the Samoan language only. I found it difficult to understand or assist her in her school homework because she did not understand the tasks to be done. Her incompetence in English slowed her progress for almost a year.

\section{Concerns of Teachers}

Of the fourteen teachers interviewed three were Samoan teachers who had used Samoan as the language of interaction with the graduates from the Aoga Amata. Of the eleven nonSamoan teachers, only two expressed concerns about the transition of the Aoga Amata children to their classes. The concerns mentioned by these two teachers were of three kinds:

i. The Aoga Amata did not assist the transition process.

For example, the lack of information on the children and their accomplishments was noted:

As Teacher 1 reported:

We did not have any records from the Aoga Amata, so we know what learning strengths the child has on entry to school, and also social skills and strategies that work in changing behaviour.

Similarly Teacher 2 explained:

No records of children's progress was received and it was difficult to identify learning needs. All pre-school records help us place new entrants into appropriate levels for learning.

ii. Lack of Samoan speakers in the staff

The school was not able to assist in the transition because there were no Samoan speakers on the staff. 
If we had resources we believe it is important to support children's first language. It is not feasible to teach Samoan language with no Samoan staff members. We rely on parents' help only. (Teacher.3).

The number of Samoan speaking children on the school roll did not warrant the provision of extra resources.

Insufficient number of Samoan speaking children to justify additional funding to provide Samoan as a language option (Teacher 4).

The remaining eight teachers did not perceive children from the Aoga Amata as having any particular difficulties with the transition. They expressed satisfaction with the social, cognitive, and literacy development of the children from Aoga Amata. In describing the positive progress of one of the children, Teacher 5 said,

Snadia is a mature caring warm young person who displays cooperative behaviour, patience, diligence and a desire to achieve that is well beyond her years. She is an intelligent student with an inquiring mind and a very able mathematician. The only skill that is still lacking in Snadia is the lack of confidence in her communicative skills where she shows a reluctance to contribute to classroom discussions.

Another teacher said,

Aso is a fast fluent reader, works hard, uses meaning well, good at figuring out what she doesn't know. Because she is such a fast thinker, she sometimes gets bored waiting for others (Teacher 6)

When the teachers were asked to compare Aoga Amata children to those who had been to other services, there were no comments that indicated that children from the Aoga Amata were being perceived as essentially different from children with other kinds of early childhood educational experiences. Two of the fourteen teachers said, "I have children from kindergarten and other pre-schools and they perform "positively" as those from Aoga Amata". 


\section{Transition Strategies}

A number of transition strategies were mentioned by the parents and teachers. Some of the strategies are as follows:

i) Accompanying the child to school

Most families used a family member, usually the mother or father, to accompany the child to school and to bring the child home after school. This family member usually stayed with the child on the first day in the class for the morning and in some cases the whole day. One mother said,

Because J... is our only child, I stayed with her in school for the whole day till school finished.

ii) Using an older brother, sister or cousin

Eight schools encouraged a member of the child's family within the school to spend time with the child in class. This procedure sometimes lasted for one or two days.

iii) Using a Samoan language teacher

One school provided a Samoan language new entrant class as part of the school's provision for Samoan children. The class was taught by a native speaker of Samoan and was available for children in the first two years at school.

iv) Special provision of cultural groups

Five schools provided Kapa Haka/Polynesian club to assist the cultural identity of Samoan children. These cultural activities are carried out once a week for some schools and once a month in other schools. 
Five of fourteen schools did not have a particular strategy for easing the transition of children from the Aoga Amata.

In summary, children who were able to join a class where Samoan was being used as the language of the classroom made the transition easily from Aoga Amata to school. Where no special language provision was available, parents experienced more concerns than the teachers did. The parents would have preferred a Samoan language class for their children, but conceded that their children quickly made the transition to English with relative ease, especially where other family members were able to spend time with the child during the transition period.

\subsection{Perceptions of the Aoga Amata Programmes}

The third research question addressed the perceptions that parents, teachers and principals had concerning the objectives, curriculum, and management of the Aoga Amata movement.

Parents were asked to describe the reasons for sending their children to an Aoga Amata, and to recall the accomplishments that they noticed in their children as a result of the Aoga Amata experience. There were also questions that probed the continuity of the Aoga Amata programme with the experience provided by the home. A contrast was sought between the development of children who attended the Aoga Amata and the children within the same family that either attended another early childhood education service, or had remained at home with caregivers.

\section{Reasons}

The most common reason advanced for sending children to the Aoga Amata was to accelerate the development of the Samoan language and to learn Samoan cultural values. Second, parents sent their children to the Aoga Amata because the fees were usually lower 
than those charged by other early childhood education services. Third, there was a general desire to support the church in its wider activities. Fourth, some families found the service convenient. It was close to home, a family member worked there, or close neighbours sent their children there.

In talking about the Aoga Amata experience, parents mentioned the way their children brought accomplishments home from the centre. For example they sang a new form of lotu, they initiated literacy experiences with family members, they brought home things they had made such as poem cards, and their art and craft work. There was also continuity between home experiences and the Aoga Amata programme. Children brought things from home to the centre: food, favourite books, toys, and clothes for the home corner.

\section{Contrast}

Four family interviews provided the opportunity to contrast the experiences of Aoga Amata children with those children who had remained at home. Children who stayed at home did not appear to receive the literacy advantage of attending an Aoga Amata. Their confidence in using Samoan was judged to be less developed than children who had had the experience of using Samoan in other settings. Their cultural understandings were also judged to be less noticeable than brothers or sisters who had gone to an Aoga Amata, as three parents stated

$P 2$

Na vave atu le faitau tusi ma iloa e Simi mea o le aoga nai lo le vaega matutua. O le fesilisili ia o Simi i mataupu tau le aoga $i$ lona fia iloa o mea uma.

P3

Na lelei atu le faitau tusi a Tolofi ma solo lelei lona facagasolo mai I le aoga. E finafinau lona mafaufau ma fesilisili I ana mea aoga.

P4

E sili atu le faaaloalo o Talia nai lo vaega lea e le i aooga i le Aoga Amata. Na te faia foi a matou-lotu o mea ai.
Simi was more advanced in his reading and other subjects than his older brothers. He was curious to find out answers to his school homework.

Tolofi was more advanced in reading and she showed better development. She has an inquiring mind and often asks questions about her school work.

Talia is more polite than our children who did not attend Aoga Amata. He usually says the grace before family meals. 
Four families were able to contrast the development of their children under an Aoga Amata and a kindergarten. Three of these families' comments on the confidence and assurance of the children who had attended an Aoga Amata are stated below:

\section{P.6}

A na ma iloa e le avea Ruth i le kindy. Na vave atu ona lelei le tautala a Senia i lo la ma teine matua. Na ala foi ona ave Ruth $i$ le kindy ona e faapea e vave ai lona iloa nanu ma sauni ai mo le aoga.

\section{P.7}

Na iloa e Malia tusi le igoa i le Aoga Amata, ma iloa foi faitau le Pi Samoa, a e le i iloa e lona tuagane tusi le igoa $i$ le fale faatoa iloa ina ua alu i le aoga.

\section{P.8}

O le ma fanau matutua sa $i$ le aoga palagi ona o aso na e le i iai ni Aoga Amata i lo matou pitonuu. Na ma iloa le eseesega o le amio a le vaega lea ma le ma tama lea laitiiti na aoga $i$ le Aoga Amata. O amio facaloalo ma le atamai e fai le lotu na ma vacia i le alii lea.
If we knew we would not send Ruth. to kindy. Senia speaks more clearly and confidently in Samoan than our older daughter. We sent Ruth to kindy so she was well prepared for primary school

\section{P.7}

Malia learnt to write her name in Aoga Amata and could read and could read the Samoan alphabet but her older brother onlu learnt this at school.

\begin{abstract}
P.8
Our older children attended the kindergarten as there were no Aoga Amata in our suburb in those days. We noticed the difference between the older ones and the younger son who attended Aoga Amata. The young one showed a respectful attitude in the home and he had the confidence to say the prayer during meal times and evening lotu.
\end{abstract}

Most parents provided two or three reasons in support of the decision to send their children to Aoga Amata.

P.9 P.9

Na ma mananao e aorar) le gagana Samoa, We wanted to learn the Samoan language ma ia ilon faaaloalo ma iloa tu ma aga faa and for her to know the culture. Simi's Samoa. O le isi foi mea o lea e faiaoga ai le mother teaches at the Aoga Amata so it was tina o le alii o Simi na faigofie lava ona la o easy for them to go together there. i le aoga.

Where two or three reasons were given, the Samoan language advantage usually preceded reasons of convenience. 


\section{Curriculum}

In recalling the development of their children over the Aoga Amata years, parents invariably mentioned emerging literacy and numeracy accomplishments, such as reciting the Samoan alphabet, writing the child's name, recognising common words, and reciting poems, and counting.

The acquisition of literacy and numeracy knowledge were the areas of first mention, closely followed by comments on the Samoan language development of the children, using terms such as confidence, fluency, and assertiveness. Vocabulary knowledge was also mentioned such as colour words, shape words, and names of animals. The ability to sing and say the lotu, to initiate traditional language games, and to use Samoan for a wide range of functions were also mentioned.

Cultural experiences were interpreted in terms of politeness and the practice of respect; spiritual experiences were linked to the close relationship between the Aoga Amata and Sunday schools. Less frequently mentioned were the experiences with play, the environment, and literacy experiences in English.

The quotations below are representatives of the comments received from parents.

$$
\text { P.9 }
$$

E lelei tele le tautala fa'a Samoa a Fetolofi. Fetolofi spoke fluent Samoan and she Na aveave sili foi i le Aoga Aso Sa a la achieved first places in our church's Sunday matou lotu school.

\section{P.11}

P.11

$O$ isi taimi e musu tele Jane. e faasino atu e se isi ia te ia se mea o le Pi faitau. E manao lava e iloa e ia tau se mataitusi o le Pi faitau. E sogasoga lona mafaufau pe a oo lava ina fiafia $i$ se mea o le aoga. A o isi taimi e fiu lava e fai atu e sau e faitau le pi e musu tele a e maise lava pe a matamata $i$ le T.V.

Sometimes Jane refuses to have someone show or tell her letters of the Samoan alphabet. She shows keenness to identify the letters of the alphabet herself. She has the willingness to find out for herself if she is interested. Other times if she's asked to read the alphabet, she is reluctant especially when she is watching television.

\subsection{Transition to Primary School}


The fourth area of focus of the study was on the teachers' perceptions of the transition to primary school for children from the Aoga Amata. There were four questions in the interview schedule that addressed the issue:

i) How did the child cope with the language of instruction during the first few weeks at primary school?

ii) How was help given to the child during the period of adjustment to an English only curriculum?

iii) What provisions were available for advancing Samoan language development in the programme?

iv) What progress did the children make in the various aspects of the curriculum?

A major purpose of the questions was to establish how teachers were constructing the Aoga Amata experiences as a factor in the decisions that the school was making.

\section{Coping with the transition}

Of the fourteen teachers interviewed, only two teachers were native speakers of Samoan. One of the teachers was teaching in the bilingual new entrants programme and received the graduates from the Aoga Amata attached to the school. The second teacher taught Samoan "once a month" to the Samoan children in the school, including children from the Aoga Amata.

The Samoan teacher in the bilingual class viewed her programme as an extension of the Aoga Amata programme but with the added responsibility of continuing the acquisition of literacy and mathematical knowledge in a systematic way. The presence of the Aoga Amata on the school grounds contributed to the familiarity of the Aoga Amata children with the school facilities. They had met their teacher many times in the Aoga Amata and she had had the opportunity to participate in experiences with the children who were about to enter her class. There was also professional contact between the Aoga Amata teachers and the new entrants' teacher. Discussions had ranged over book experiences, mathematical activities, and imaginative experiences. Resources were shared, and the 
exchange of views occurred in respect to the development of writing. Teacher commented,

Tuи pea le tusitusi a tamaiti ia te au le faiaoga tulaga lua, o la'u galuega lena $e$ fai. E faigata tele ona tau faasa'o tamaiti pe a o mai i le aoga ua masani $i$ le tusiga le sao o le mataitusi (Teacher 12).
Leave the writing to me the primary school teacher. That's my job; teaching the children how to write. It is often difficult to try and correct the children when they come to school already familiar with the incorrect letter formation in writing (Teacher 12)

The second Samoan teacher assisted in the new entrant class and helped with the adjustment of newly arrived children from the Aoga Amata. She remarked on the social maturity of the children and the confidence in activities where they were able to use Samoan and cultural knowledge.

E fiafia tele tamaiti mai le Aoga Amata $e$ faamatala tala mai $i$ o latou aiga i taimi o tala o le taeao. O nei tala e faa Samoa lava ona facimatala. O pesega ma tauloto faa Samoa o le Lotu a Tamaiti e fiafia tele e fai i le aoga. E faapena foi ona latou faaaoga le gagana Samoa i taimi e taaalo ai, ma fai ai galuega tau numera. (Teacher 13).
The children from Aoga Amata were usually confident to tell news from their homes during Morning Talks. These news were told in Samoan. They liked to sing and recite their memory verses for White Sunday in school. Similarly, they used Samoan language to interact in their games and mathematical activities (Teacher 13).

Eleven of the teachers viewed the Aoga Amata experience as valuable, and were able to mentio: qualities they saw in children who had graduated from the Aoga Amata. As one teacher said They came with good social and literacy skills (Teacher 14).

Similarly another teacher remarked, Tua is a pleasant child who often offers to help in class. He is progressing well in his maths and appearing an outstanding class leader (Teacher11).

Only one teacher had reservations about the Aoga Amata experience, as she understood it in thi context of one child. She mentioned the lack of information about the development of the chilk and was not aware of any attempts to address the child's particular needs in the Aoga Amat: programme. 
No, I don't think the Aoga Amata has helped him. There was no record of his development kept and he does not need a bilingual programme because he is a fluent English speaker (Teacher 9).

\section{Facilitating the transition}

Where Aoga Amata children were being enrolled in an English-only classroom, the most common form of assistance was the use of older Samoan speaking children who were related to the children concerned, or well known to the children. These special helpers were withdrawn from their own classes to spend up to two hours a day with the children. This arrangement lasted for two days, or a week or two, and on one occasion as long as a month. One parent said,

His older brother in the senior class stayed with him only for a while until he was happy to join other children in class activities.

Teachers also mentioned the role of parents and relatives. They would bring the children to school, stay with them for a while in the classroom, and perhaps come early to be with them at the end of the day. On some occasions, caregivers spent the entire day with their children during the initial weeks at school. This arrangement was used frequently by mothers who had only one child. The mother commented,

Talu ai ona e na o le tasi la ma tama, ou Because we have only one child, so I stay te nofo ai lava $i$ le aso atoa seia tuua le aoga ma o i le fale. at school with her till school finishes then we go home together.

Two schools used non-teaching staff who were speakers of Samoan to assist with the transition. Typically they would come into the class on the request of the teachers when language assistance was needed.

\section{Provision for language maintenance}

Children from the Aoga Amata are bilingual in at least two senses of the term:

a. They are monolingual speakers of Samoan in an English language speaking environment.

b. They have two first languages, Samoan and English. 
The New English Curriculum Statement (Ministry of Education, 1996) specifically directs that the language of a child's home have a place in the curriculum. The Taiala, (Ministry of Education 1996) provides curriculum guidelines for the development of proficiency in Samoan across eight levels. In the present study there was wide variation in the way these documents were directing language programmes in the primary schools of the teachers interviewed.

One school, as discussed above, had a Samoan English bilingual class that a child could be enrolled in for two years. One school had a teacher who met the Samoan speaking children from the new entrants class once a month with other Samoan speaking children at the school. In all, there were sixty-seven children in one space and this teacher commented on the difficulties she encountered with this arrangement.

Having sixty-seven children in one room with only two teachers for Pacific Islands studies or cultural activities is absolutely poor management and a very unfair way of meeting the needs of these children. It all goes down to the availability of funds.

Some schools viewed their language maintenance obligations as met through the provision of Polynesian clubs, Kapa Haka, and a Social Studies programme integrated with Pacific Studies as one principal commented,

We have no Samoan classes but we integrate our Social Studies programmes with the Pacific Studies. The school has a Polynesian club where children from the Pacific participate using their own language through songs and dances.

At least three schools disclaimed responsibilities for language maintenance citing the pragmatic difficulties of meeting the language needs of all their non-native speakers of English. As one principal put it:

This school has a lot of children from other ethnic groups. We concentrate on the teaching of English and the parents know this. In Wellington they have a choice of schools such as Newtown, Mt.Cook, Brooklyn or Strathmore (Principal 1). 
Unlike the above principal who sees the maintenance of the Samoan language as an issue for the school, the second principal expressed an interest in doing this work provided funding was available.

We would like to provide Samoan language classes but the lack of human resources and funding prevented this (Principal 2).

This arrangement was further supported by claims that parents wanted the responsibility for language maintenance to be with the home and the church, with the school assuming responsibility for English language development.

\section{Teachers' perceptions of progress}

All but one of the teachers in the sample viewed the Aoga Amata children positively when asked to comment on their progress.

When asked to be more specific, teachers mentioned the performance of children during book experiences and during mathematics as being particularly pleasing, especially when compared to the performance of children who had not attended an early childhood education centre. One teacher commented,

I had no difficulty with Aoga Amata children. They appeared very confident and well settled in their first few days in school. Some non-Aoga Amata new enrolments seemed timid and reluctant to socialise.

The results concerning children's comentencies are consistent with the findings of a study of New Zealand five year old by Wylie (1996).

The one teacher with reservations was not sure of the value of the Aoga Amata experience in the context of the general developmental needs of the child concerned.

\subsection{Factors Affecting Samoan Language Maintenance}

The last research question addressed in the interviews concerned the factors that were perceived to be contributing to the maintenance of Samoan. When parents gave their views they stressed the role of the home, the church, and other community initiatives. Of special 
mention was the role of grandparents, and other relatives that might be living with the family. The opportunity to take a child to Samoa and live in the village environment for a short period of time was also mentioned.

The parents also saw the school as having an important role. Without exception, the parents interviewed wanted the school to have a Samoan language programme following the principles of the Taiala. They had sent their children to an Aoga Amata to consolidate their children's Samoan language proficiency and would welcome the school finding a role for Samoan in their children's education. The parents were committed to bilingualism but wanted English and Samoan to be acknowledged as the first languages of their children.

Parents who spoke different heritage languages agreed that Samoan was important in the development of their children for cultural and spiritual reasons. The language was seen as the basis for developing values such as respect, reciprocity, and concepts of obligation.

The teachers and the principals saw the maintenance of Samoan as "desireable", but frequently cited funding, and human resourcing arguments to justify the lack of provision in their schools for language maintenance.

Two principals argued that the Samoan parents wanted to have the responsibility for teaching Samoan to their children, thereby freeing the school to concentrate on English and the other clements of the curriculum. It should be noted, however, that the parents who were sending their children to that school did not express this view to the researcher during the interviews.

One principal argued that it was well publicised that his school did not have provisions for language maintenance. Parents knew which schools in Wellington did and hence were able to exercise a choice.

\subsection{Summary and Discussion}

Thirty-nine _parents, fourteen teachers, and fourteen principals gave their perceptions of how the transition from Aoga Amata to primary schools, impacted on children and was managed by the receiving teachers. Language and cultural reasons were advanced by 
parents for enrolling their children at a local Aoga Amata. The parents as well as teache and principal of the receiving schools viewed the Aoga Amata experience as valuable. Tl transition was managed by the families and the schools through using a variety strategies:- family assistance, the assistance of other Samoan children at the school, the u of non-teaching staff who were speakers of Samoan, and in one school through a bilingu programme. The Aoga Amata assisted in the transition through the curriculum of $t$ centre, the experience visits, and through informal contact with teachers at the receivit schools. The Aoga Amata did not however provide written records of the children and the development, a point emphasised by some teachers and school principals.

Schools recognised the importance of language maintenance, but except in one case we not able to provide bilingual education during the transition period. Parents were able articulate their desires to have their children grow up bilingually in New Zealand. Th were aware of the family's role in achieving bilingualism and the school's role in Engli language development, but the families were seeking new initiatives to link the home al the school through the language education of their children. 


\section{CHAPTER FIVE}

\section{CASE STUDIES}

\section{E toatele e na valaaulia a e toaitiiti ua filifilia}

Many were invited but a few were chosen

\section{$5.1 \quad$ Introduction}

This chapter focuses on case studies of six children who range in ages from $6-11$ years.

Table 5A provides background information on the case study children.

Table 5A Summary of Case Study Children

\begin{tabular}{|llll|}
\hline Case & Gender & Age & \multicolumn{2}{c|}{ Provision of Samoan in the school curriculum } \\
1. Miriama & Female & 8 & Yes \\
2. Talia & Male & 7 & Yes \\
3. Puipuiau & Female & 9 & No \\
4. Potoa'e & Male & 6 & No \\
5. Maxine & Female & 11 & No \\
6. Sia & Female & 6 & No \\
\hline
\end{tabular}

Two students, one female and one male, are attending primary schools which provide Samoan language curriculum opportunities. Detailed discussions of these cases are presented in sections 5.2 and 5.3, respectively. In contrast, the next two case students, one female and one male, attend schools with no provision for Samoan in the curriculum. Results from these students are the main focuses of sections 5.4 and 5.5. The remaining two cases, both females, attend primary schools again with no provision for the Samoan language, but their progress appears significantly different from the previous children in the sample. Sections 5.6 and 5.7. provide details of these cases. 
Each case study contains details of the background and home environment of the child, recollections of what was acquired from the Aoga Amata experience, the perception of teachers and parents about the Aoga Amata programmes, and the transition of these children to primary schools. Information from the principal of the school about the reasons why the school has or does not have provision for teaching the Samoan language is summarised and related to the educational situation of the child.

The special case studies of the last two female students follow the same format but focus in particular on the difference in progress shown. These differences are detailed under the appropriate subheadings. The overall results of the children will be summarised with comments in section 5.8.

\subsection{Case Study One: A Female Student Who Experienced Samoan Language in School}

Miriama is an eight year old female student. She was one of 20 children who experienced Samoan language in the home, Aoga Amata as well as in the primary school. This section discusses in greater details Mirirama's progresses in education.

\section{Family background and home environment}

Miriama was born in the Lower Hutt hospital and she lives with her parents and auntie in Naenae, Lower Hutt. There are seven people in her family, three adults and four children. Miriama is the oldest child of the four and she communicates fluently with her parents and other members of the family in Samoan at home. The father is employed as a welder, and the mother is a housewife. Both parents are Samoans who arrived in New Zealand in 1983.

The parents set rules for their children in the home. One of these rules is that Samoan is the only language to be spoken at home. Even the church they attend encourages children to speak Samoan, as all the services and biblical activities are conducted in Samoan. Miriama's first language is therefore Samoan, the language acquired by her during infancy and early childhood within her family environment. 


\section{Aoga Amata experience}

Miriama spent three and a half years in one Aoga Amata at Naenae, where she learnt to read and recite the Samoan alphabet, could write her name and surname, and count by rote from 1-50 and she could also read two-letter words in Samoan. Her mother recalled that Miriama was apprehensive when she first joined the Aoga Amata, so the mother stayed with her for almost two months until she settled in. The parents observed her in the Aoga Amata as obedient, quiet and very willing to engage in the curriculum of the centre, especially in drama. At home they enjoyed listening to Miriama singing songs and reciting poems she had learnt at the Aoga Amata and were pleased with her education there, as she appeared to grow in confidence in her use of Samoan.

\section{Primary school experience}

When Miriama turned five she attended one of the Catholic Schools in Naenae, where some of her cousins were enrolled. This made it easier for her first day at school. Although Miriama was happy, she initially found it difficult to understand her teacher who was using English as the major language in the classroom. Miriama's teacher is herself Samoan and Miriama was able to use the Samoan language in one-to-one interaction with her teacher. The school provides a Samoan class, but that meets only monthly. According to her teacher, Miriama acquired English rapidly and coped very well with the programme. The parents reported that the school subjects which she liked best were: reading, and language with music, and art. The assessment of her curriculum subjects by the teacher are given in Table 5B below:

Table 5B Miriama's subject assessment

\begin{tabular}{|l|l|l|l|l|l|l|}
\hline Subjects & Maths & Science & Reading & Story writing & Languagc & Spelling \\
\hline Assessment & Good & Good & Very Good & Good & Satisfactory & Excellent \\
\hline
\end{tabular}


Miriama is participating confidently in all of the above subjects including music, sports and in the Polynesian Club. Her attendance is excellent and her overall performance is rated as very good to excellent. (See Table 5.C).

Table 5C Miriama's overall assessment in development

\begin{tabular}{|l|l|l|l|}
\hline Area of Development & Academic & Social & Behaviour \\
\hline Assessment & Very Good & Excellent & Excellent \\
\hline
\end{tabular}

\section{Provision of Samoan Language in school}

The school provides a Samoan language programme but it is taught only for an hour once a month. Although Miriama experienced difficulties with the transition to English when first starting school, it was fortunate for her that she was put in a class where the teacher was Samoan. The fact that Miriama could speak to her teacher in Samoan, and get a reply in English, seemed to assist her initial acquisition of classroom English. In the opinion of the teacher, an additional facilitating factor appeared to be the secure language development in Samoan that she was receiving at home, and in her immediate community.

The total roll of the school was 122 and the number of Samoan students was 67. Although about half of the school children were Samoans, there was only one Samoan teacher on the staff, and hence the reason why the Samoan language was taught only for an hour, once a month. The content of the Samoan programme includes custom, language, dancing and singing.

Furthermore the principal commented, "Children should be exposed to their own culture and the culture of others". The principal also acknowledged that the situation of having just one hour in a month to teach Samoan language was nowhere sufficient to cater for the maintenance of Samoan when children came to school speaking Samoan as a first language. 


\section{Teacher's perceptions of the transition to school}

The general perception of the teacher was that students who did not have pre-school experience generally had difficulties adjusting to school. In the teacher's opinion, the children who had attended an Aoga Amata, had usually acquired acknowledge of the basic mathematical terms and concepts. They also had acquired basic reading skills, such as good letter sound recognition, good control of a pencil, and an understanding of the simple additions and other mathematical tasks. This helped them (teachers) extend their (children's) skills and to develop further learning activities to suit their levels. Miriama had displayed all these skills.

\section{Parents' perception of child's progress}

The parents' main reason for sending their daughter to an Aoga Amata was to understand the Samoan culture and to accelerate her Samoan language development. They selected the primary school for their daughter because they knew the Samoan language was taught there and was the only school in the area that provided it.

As yet, there were no concerns expressed by the parents about the education that their daughter was receiving. They said she is still in the lower classes and is enjoying school. Her father added that Miriama often comes first in Sunday school exams and therefore they were both happy with the progress she was making so far.

\section{Other significant information}

During school visits, the parents were critical of the behaviour of some students and they commented, " The teachers should also concentrate on the behavioural control of students in classrooms as well as the basic teaching of the curriculum". The parents recalled their experiences of schools in Samoa where children behaved very well when the teacher was around. 


\subsection{Case Study Two: A Male Student Who Experienced Samoan Language in School}

Talia is a seven- year-old male student. He was one of 20 children who experienced Samoan language in the home, Aoga Amata as well as in the primary school. This section discusses in greater details Talia's progresses in education.

\section{Family background and home environment}

Talia's parents were both born in Western Samoa. His father arrived in New Zealand in 1974 and his mother arrived the following year. They lived with their children in Miramar, Wellington. The father was a welder and the mother was a teacher at an Aoga Amata in Strathmore where Talia, the fourth and the youngest of their four children, attended till he turned five.

Talia communicates confidently in Samoan at home with his parents, his older brothers and also at the church in which activities are all conducted in the Samoan language.

\section{Aoga Amata experience}

The Aoga Amata is situated in the Strathmore area and is attached to one of the primary schools. His mother was the teacher at the centre. Talia attended the centre when he was only a few weeks old, and he was there for five years.

Before Talia attended primary school, he knew how to write his name and surname and could count numbers from $1-120+$. He could order objects by size, and could recognise a few colours in Samoan for example, pa'epa'e (white), uliuli (black), piniki (pink). He could also recite the Samoan alphabet and recognised most of the letters. Talia was able to respond to instructions and engage in simple tasks.

\section{Primary school experience}

Talia attended one of the primary schools where his older brothers were enrolled. The school has a roll of 97 pupils and almost three-quarters of the total roll are Samoan 
children. The school has eight staff members; three of them are Samoans including the principal. The deputy principal is Maori and there are four European teachers.

There is a Samoan class in the junior school. The Aoga Amata graduates attend this class when they reach primary school age. The teacher is a Samoan and delivers the curriculum bilingually, with a primary emphasis on Samoan. The establishment of the Samoan class is designed to cater for the Samoan pupils who attend the school and speak Samoan as a first language.

\section{Provision of Samoan Language in school}

It was easy for Talia to cope with his new school environment because he was admitted into a class, which uses Samoan as the language of instruction. Talia met his friends who had attended the same Aoga Amata and he had no fear of participating in the learning activities. He continued speaking Samoan language and this helped him extend his vocabulary and story writing. In fact the skills which Talia had in reading the Samoan alphabet while in the Aoga Amata assisted him to recognise letters of the English alphabet as well. The parents had no difficulties with Talia as far as his learning was concerned.

During the interview I asked Talia if he liked his new school and he replied,
E fiafia a'u i le aoga, a o isi kaimi e
I like school but sometimes I ma'i au e gofo ai i le fale. get sick so I stay home.

Talia likes maths, reading, story writing and physical education. He speaks hoth Samoan and English in school and he also speaks these two languages at home and at church.

Learning for Talia seemed to flow steadily in the school as he moved from the Samoan class to the next class level, where the Samoan teacher continued to implement programmes in the Samoan language. 


\section{Teacher's perception of child's progress}

The teacher found Talia very pleasant and polite. His attitudes to school were positive. He participated well in learning activities, and his attendance was very good. The teacher rated Talia as 'excellent' in coping with the language of instruction. The assessments made by his teacher in his favourite school subjects are shown in Table 5D below:

Table 5D Talia's subject assessment

\begin{tabular}{|l|lllllll|}
\hline Suhjects & Maths Reading & Science & Language & Story Writing & Spelling & Marri & Phys. Ed. \\
\hline Assessment & Very good Very good & Very good & Very good & Very good & Very good & Good & Very good \\
\hline
\end{tabular}

His overall performance was rated as "Very good" for academic, social and behavioural development.

\section{Parents' perceptions of child's progress}

Of the four children in this family, the parents found Talia a totally different child to his older brothers. Talia appeared more mature, polite and more advanced academically.

When I asked the parents why Talia was different they replied that their older boys attended European pre schools because at the time. there were no Aoga Amata pre schools. Talia developed his reading skills a lot faster and was able to reald two or threeletter words while still in Aoga Amata. According to his father Talia showed more cultural respect in the home than his older brothers. The father said:

E tele mea aoga ua mana mai e Talia mai le Aoga Amata; ua muamua fai le lotu pe a 'ai. E facafetai mai i a maua pe a uma ona 'ai (Fatefetai kuka). E na te facamanatua mai i a mana le lotu a le aiga i le afiafi. ia ma ua iloa lelei le faitauina o le Pi faitau Samoa .
Talia learnt a lot of useful things from Aoga Amata: he says grace before e'ating, thanks uss after centing $H_{e}$ alsor reminds us about the family's c'rening prover if we forget, and he recites the Samoan alphabet comfortably.

The father then went on to say, 
Na tau faalata le vaega matutua e lo la tina ina ua o i le aoga tulaga lua. E le $i$ nofo se isi i a Talia, na fiafia lava ia e nofo i lana vasega fou i le uluai aso na ulufale ai i le aoga. E atamai atu ma vave le piki a Talia nai ona uso.
Mother stayed in school to keep the older boys settled. We did not have to stay for Talia's on his first day as he settled in very well. He cuppeared more intelligent and was quick to learn in school than his older brothers.

\section{Other significant information}

The whole interview with Talia was conducted in the Samoan language and he appeared relaxed and was at ease throughout the interaction. The mathematical activities and simple tasks were well understood.

\subsection{Case Study Three: A Female Student Who Experienced No Samoan Language in School.}

Puipuiau is a nine-year-old female student. She was one of 20 children who experienced Samoan language in the home, Aoga Amata but not in school.

\section{Family background and home environment}

Puipuiau lives in Porirua with her mother, grandmother and her auntie and uncle. Her uncle is Tokelauan but the rest of the family members are Samoan. Puipuiau's parents separated while she was a baby and the mother brought her daughter up als a single parent. The Tokelauan uncle has been the father-like person in Puipuiau's upbringing.

Puipuiau attended the church's Aoga Amata hefore she began in one of Porirua primary schools, which was close to her home. Then her family shifted to another Porirua suburb where she attended another primary school, again the closest one to her new home.

Her grandmother is the senior member of their household who speaks only Samoan.

All the family members communicate with Puipuiau in Samoan and so she speaks Samoan all the time at home and sometimes in the church. She speaks English in school. 
Puipuiau's mother works as a nurse in one of the local hospitals where she is timetabled Io work rotating shifts. Her sister who stays home to look after the grandmother attends to Puipuiau's school lunches and school uniform whenever Puipuiau's mother works early morning shifts. Her brother in-law takes Puipuiau to school by car and picks her up in the afternoon. Puipuiau's mother helps her at home with reading, spelling and simple maths homework. Puipuiau's uncle and auntie also assist her with some of her homework whenever her mother works in the evenings.

The family attends the Presbyterian Church in Porirua where morning eleven o'clock services are conducted in English. Every Sunday, except the first Sunday of the month. they attend the three o'clock afternoon service, which is conducted in the Samoan language. Puipuiau listens to the sermons and participates fully in the church activities in that language.

\section{Aoga Amata experience}

Puipuiau attended the church's Aoga Amata for two years. The Aoga Amata was established in 1992. Only two teachers catered for a group of almost 30 pupils, and the parent helpers assisted with the preparation of morning tea and the setting up of the play area and activity corners for the various sessions (9 am - 12 pm on Wednesday, Thursdaly and Friday every week).

When Puipuiau's mother was asked of the reason why she sent her daughter to the Aoga Amata she replied:

Ina ia facamasani atu ma isi tamaiti, ma maua foi sona malamalama $i$ le olaga facatcimaitiiti.
So she can socialise with other children and to anderstand what other children are like.

Puipuiau learned to spell and write her first name and surname. She could count from I 10 and she recognised four colours in Samoan while in Aoga Amata, for example, lanumoana (blue), lanumeamata (green), mumu (red), and samasama (yellow). She could also sort objects in order of size, complete simple additions, and understand simple tasks. 
According to the mother. Puipuiau learnt to reald the alphabet and short sentences in Samoan at the Aoga Amata. She was happy al Aoga Amata. Her mother further commented:

Ua fiafia ua ia feiloai ai ma isi tamaiti ma ua maua ana pese ma tauloto fou.
She is happy that she meets other children and she learns new songs and poems.

\section{Primary school experience}

Puipuiau attended one of the local primary schools close to her home in Porirua. The total roll for the school was 205 with eight teaching staff members. Among this number are 63 Samoan children. So it is closer to one-third of the total roll of the school are Samoans.

There was no Samoan teacher in the school, only one Tokelauan who had recently joined the school and one Maori who was a first year teacher.

Puipuiau likes music, art, drawing. writing, maths, reading, and sport. She did not like Science, or physical games like cricket, or painting as she said, "It dirtied my clothing". Although she usually speaks English at school, she can still write short stories in Samoan although not very well.

\section{Provision of Samoan Language in school}

As there was no provision for teaching Samoan in the school, learning for Puipuiau was not easy during her first year of school. She had a non-Samoan speaking teacher and her friends were the only people who could assist her during learning activities in class. Puipuiau's mother was concerned, as she found her slow when trying to help her with homework from school.

The school principal was interviewed about the Samoan language provision in the school and she replied:

"Yes, the Samoan language should be taught in this school as it is the language of many of our students and a growing number have had Aoga Amata pre-school experience. I asked the parents two years ago and the questionnaire was sent home about the establishment of Samoan language in school, but most Samoan parents did not want it. They wanted to leave the Samoan language for them to teach at home". 
The school would have established a Samoan language class if the parents responded positively to the questionnaire. Alternatively, it is interesting to know how the parents were informed before the questionnaire was sent home.

\section{Teacher's perceptions of child's progress}

When the teacher was asked during the interview about how Puipuiau coped with the language of instruction she said:

Satisfactory, but at times she (teacher) needs to break it down with other support. Puipaiau continues learning Samoan in school in an informal way. She is a member of the Kapa Haka/Polynesian club where she converses with friends in Samoan.

In the various areas of learning, Puipuiau is rated as "satisfactory". The teacher further commented,

Puipuiau is a very able student in any area but reluctant to take responsibility for her own learning. She tends to be lazy.

Please refer to Table 5E below on how Puipuiau was assessed by her teacher in three areas of development.

Table 5E Puipuiau's overall assessment of development

\begin{tabular}{|l|l|l|l|}
\hline Area of Development & Academic & Social & Behaviour \\
\hline Assessment & Very good & Pretty good & Improving this year \\
\hline
\end{tabular}

According to the teacher, Puipuiau particularly likes maths, reading, spelling, music, story writing. sports, Polynesian club and science but she is reluctant to take part in drama because she appears indifferent about taking risks when communicating in English. Her attendance at school is very good.

The present teacher said that Puipuiau attended another primary school straight from Aogal Amata, before she came to her present school. The teacher commented that she received no record of Puipuiau's Aoga Amata experience. 


\section{Parents' perceptions of Aoga Amata and the transition to school}

The mother was happy with her daughter's education at the Anga Amata. Some of the reasons advanced for enrolling her child at the Aoga Amata were:

Fiafia aua ua mafai ona faalauteleina le malamalama o Puipuiau $i$ le tele o nisi mea e sauni atu ai mo le ulufale atu i aoga tulaga lua. Nisi o mea sa le maua ai se taimi o matua $i$ le fale ma le tamaitiiti a e ua piki mai le Aoga Amata.
I was happy because Puipuiau could extend her knowledge in some of the things in preparation for entering primary school. Some of the learning activities which were not carried out at home, as there was no time with the child, were picked up from Aoga Amata

Puipuiau was happy to attend primary school according to the mother, who said,

Ua fiafia ua atoa le aso, ua ese foi le tulaga ua iai, ona of faiaoga palagi, ua fefiloi ma isi tamaiti o nisi gagana, ma atunuit.
She's happy as she's out for the whole day but finds it a little strange with new European teachers and a mixture of children from other ethnic groups.

Despite the happy attitude towards school, the mother found Puipuiau diffident about talking about school at home. Her mother often asked her about what happened in school but Puipuiau would only respond: Tailo, ou te leiloa. (I don't know:)

The mother interpreted her daughter's reluctance to talk about school in the following way:

Faigata ona malamalama ona e le masani ai ona faalogo pe tautala faaperetania. E fou foi i lana faalogo le tele o le gaosa o le gagana Peretania. Sa amata mai lava Puipuiau $i$ le gagana Samoa ma tautala ai lava.
It was difficult because Puipuiau was not used to listening to English being spoken. The different concepts of English language were all new to her. Puipuiau was brought up in the Samoan langatage and that was the only language she could speak. 
When the mother was asked about the help Puipuiau was given al school for her learning she replied that her friends helped her. Often Puipuiau did not understand her homework, which she brought home from school. This was of considerable concern for her mother.

During discussions about her homework, the mother noticed that maths and science were the subjects that Puipuiau disliked most at school. She suspected that the cause of this was related to the use of English as the language of instruction.

The mother endorsed the establishment of a Samoan language curriculum at the school, as this might be the opportunity for some students to learn and study their own mother tongue. She commented,

E taua ona iloa pea e le tamaitiiti lana gagana ma faigofie ai foi ona feagai ma ona matua ma isi tagata.
It is important for the child to know his own language for communication with the parents and other people will he easier.

Puipuiau gets the support from her mother in most of her homework. Her mother advises her to use her time wisely and encourages her to read and revise her work. Puipuiau is able to read the Samoan bible fluently.

\section{Other significant information}

During parent interviews the schoolteacher reported that Puipuiau was capable of better learning but she sometimes lacked concentration and showed unacceptable behaviour. The mother thought that the English-only nature of the curriculum was the reason for these adverse comments.

\subsection{Case Study Four: A Male Student Who Experienced No Samoan Language in School}

Potoa'e is a six-year-old male student. He was one of 20 children who experienced Samoan language in the home. Aoga Amata but not in the primary school. This section discusses greater details of Potoa'c's progress in education. 


\section{Family background and home environment}

Potoa'e, the youngest of four children, was born in the Wellington hospital in Newtown and now lives with his parents and two older brothers and sister in Miramar. Because his mother is a student at the College of Education in Karori, the children all attend the closest school to her studies.

Both Potoa'e's parents were born in Samoa. Her mother arrived in New Zealand in 1964, while the father, who is currently employed as a Telecom Administrator, arrived in 1966. They speak both English and Samoan at home but use English predominantly between themselves and their children. Both languages are also spoken in their church services and church activities.

At home between $3.30 \mathrm{pm}-5 \mathrm{pm}$ the parents spend time with the children in shared reading and writing activities. They often read stories to Potoa'e as he likes being read to. The children also have access to a home computer. As the mother said:

We provided a home computer which he (Potoa'e) has allocated time to. This allows him to continue writing stories on the computer. Our family has a structured routine, i.e. Homework time - Dinner - Free time - then Bedtime hours. At home Potoa'e likes playing with his toys, watching television, reading, writing and going shopping.

This family expends considerable effort to support the education of their children and they have high expectations that they will do well in school.

\section{Aoga Amata experience}

According to the parents, they sent Potoa'e and all their children to the church Aoga Amata for the morning sessions because it was convenient for them. and to the kindergarten in the afternoon sessions. It was also the cheaper option as the Aogal Amatia was attached to their church. One other important reason for sending their children to the Samoan pre-school was to promote their awareness and use of the Samoan language. 
At the Aoga Amata, Potoa'e learnt how to write his name and surname, hut remained uncertain about the spelling of both. He could count numerals from I - 19, name some colours e.g. lanu meamata (green), samasama (yellow). lanumoana (hlue), and could understand simple tasks in Samoan. During his time at the Aoga Amata, he spoke Samoan at home more frequently than is the case at present.

Potoa'e was reluctant to stay at Aoga Amata on the first day. His mother attributed his reluctance to the unfamiliar and new environment. He later became happy to be with other children and he consequently spent 2 years. From 1994 - 1996, Potoa'e attended a kindergarten for the afternoon sessions, as the parents considered it was valuable experience in preparation for school.

\section{Primary school experiences}

As mentioned before, Potoa'e attended one of the primary schools in Karori, as it was convenient for his mother who was training to become a teacher at the College of Education. The school roll was 650 but only 8 students were identified as Samoan. Potoa'e had no difficulty settling into his new school on his first day. His mother commented:

More accepting of the new environment. Showed no signs of fear or reluctance among a whole new set of children and adults. He did not find English difficult to understand.

Because Potoa'e had two first languages, Samoan and English, he did not appear to have difficulties in adjusting to an English-only classroom.

The parents have noticed that Potoa'e likes reading, story writing and physical education the best, but the teacher has commented that he also works well in maths, music, science. and sports. He coped very well with the language of instruction. The teacher's assessment of his progress in the various areas of the curriculum is presented in Table $5 \mathrm{~F}$. 


\begin{tabular}{|c|c|c|c|c|c|c|}
\hline Subjects & Maths. & Reading & Language & Phys Ed. & Science & Story Writing \\
\hline Assessment & Very good & Very goxl & Very gocol & Very goxd & Very groxl. & Very good. \\
\hline
\end{tabular}

Overall his developmental assessments are: academic (good), social (good), and behaviour (good). His attendance and health are both very good. At this stage of his schooling, the parents have no concerns about his progress. The parents appear to be monitoring their children's education, with regularity and care. The mother confirmed this approach during the interview and said,

From Monday - Thursday each week, Potoa'e spends at least 20 minutes daily on his homework and he often asks us for help in his reading or writing.

\section{Provision of Samoan Language in school}

Opportunities to study and use the Samoan language are not provided in the school, thus depriving Potoa'e from informal education using his heritage language. Now he speaks English in preference to Samoan at home and at church. The principal does not think that the Samoan language should be taught in the school. mainly because of the small number of Samoan speaking pupils on the roll.

\section{Teacher's perceptions of the child's progress}

The teacher had no specific concerns about Potoa'e's transition to school. Potoale seemed comfortable in the new entrants class, and is now progressing well in all his school subjects. The teacher did not see a need to have support for Potoa 'e's hilingualism, partly because he is such a proficient user of English.

\section{Parents' perceptions of Aoga Amata and the transition to school}

The parents found the Aoga Amata to be useful for the learning of Samoint. because there. Potoa'e would speak more Samoan than he might have otherwise done. However, 
the parents raised the following issues:

Loudness in speech - Discipline seemed to be lacking with regards io running around inside the facility. Children's artwork appeared in some cases to be done mainly by teachers not the child. e.g. colouring in.

The parents again answered the question of whether they were happy with the education of their child in Aoga Amata and they replied with both a "Yes" and "No" as recorded below:

Yes, because of the language nest concept, vet there was a lot of room for improvement. At the time it would have been more suitable for us if it had been full daycare. No, as later in the afternoon sessions, it appeared to be lacking in creative, organised, age ability set activities. There was a greater variety of activities for the older children.

As for the transition, they said that Potoa'e had adjusted to the new school and environment very well. He was fortunate to have his older brothers and sister there at the same school. The parents supported the teaching of Samoan language in the school with the following suggestion: "If it can be resourced and sufficiently funded by competent staff or expert people in the field of teaching the Samoan language". Their final comment was that they wanted their child to maintain his Samoan language heritage when he becomes an adult.

\subsection{Case Study Five: A Female Student Who Experienced No Samoan Language in School}

Maxine is an eleven year old female student. She was one of 20 children who experienced Samoan language in the home, Aoga Amata, in the church but not in the primary school. This section discusses in greater details, Maxine's progress in education and the support of her parents and grandparents to maintain her Samoan language.

\section{Family background and home environment}

Maxine's parents were born in Western Samoa and they arrived in New Zealand in 1975. They live in Island Bay, Wellington. Maxine was born in Wellington Hospital and she is the second child from a family of five. She attends one of the intermediate schools in South Wellington and she speaks fluent Samoan. Her family is one of the willing supporters of one of the churches in Newtown. Wellington. Maxine's family speaks 
Samoan at home and in church activities.

Maxine lives with her parents and grandparents from her paternal side. There are ten people in this household, five adults and five children. The grandparents speak only the Samoan language and this assists Maxine greatly in the maintenance of her first language. Samoan is the natural language of the household. Maxine's mother is a teacher and a supervisor in one of the Aoga Amata that Maxine attended during the first five years of her life. Her father works during the day as a machine operator. The parents, particularly her mother, assists Maxine in her primary school maths, spelling and reading homework whenever she has difficulties.

\section{Aoga Amata experience}

Maxine attended the Aoga Amata in Newtown for five years. This Aoga Amata was first established in 1985 and is the first one in the Wellington region to be licensed.

Maxine learned how to spell and write her name and surname while at Aoga Amata. She knew how to count numbers from $1-100+$ by rote methods. She was also able to arrange objects according to their sizes complete simple additions and carry out simple tasks. Samoan was the language of instructions throughout the day and she spoke and understood it well.

\section{Primary school experience}

Maxine spoke only Samoan language when she left the Aoga Amata and began her primary schooling. At first she found it very difficult to communicate with her nonSamoan speaking teacher and with other children in the class. Her Samoan friends and relatives helped her during her few days at school. However, it did not take long for Maxine to acquire English. She adapted well to her new environment, als there was a Samoan teacher at the school who showed a special interest in her progress.

Maxine now attends one of the intermediate schools in South Wellington, where she enjoys studying mathematics, sewing, cooking and metal work. Although Maxine speaks Samoan everyday at home, at church and sometimes at school, she finds that English is 
the language that she now uses more frequently.

The school's Polynesian club is one of Maxine's favourite activities. She fully participates in the programme and leads the Samoan section confidently.

\section{Provision of Samoan Language in school}

The school did not provide a role for the Samoan language as a regular part of the curriculum, but sometimes a special option a programme was provided during electives to maintain first languages.

At first it was difficult for Maxine to participate in class discussions because of her inexperience with English. However it did not take long for her to get accustomed to the class activities as she acquired English language relatively quickly, with the help of her friends and the Samoan teacher at the school. So learning for Maxine was quite difficult, but with the help and special consideration, she was able to adjust comfortably to the use of English and prove herself to be a very capable student in all areas of the curriculum.

\section{Teacher's perceptions of transition to school}

According to her teacher Maxine works well in maths, story writing. reading. spelling, science and sports. Her school subjects have been assessed in Table 5G below in terms of how she copes with them:

\section{Table 5G Maxine's subject assessment}

\begin{tabular}{|l|lll|}
\hline Subjects & Maths & Realding Language Phys.Ed Spelling Story Writing Science \\
\hline Assessment & Excellent Very Good VeryGood Excellent Excellent Very Good Very Good \\
\hline
\end{tabular}

Her school attendance and health are both rated 'excellent'. Her overall performance is rated as follows (Table $5 \mathrm{H}$ ) 
Table 5H Maxine's overall assessment of development

\begin{tabular}{|l|l|l|l|}
\hline Area of Development & Academic & Social & Behaviour \\
\hline Assessment & Excellent & Excellent & Excellent \\
\hline
\end{tabular}

This represents significant progress for a girl who left Aoga Amatal ats a first language speaker of Samoan and had to adjust to a school curriculum experienced through the medium of English.

The teacher commented that Maxine's attendance at Aoga Amata helped her in her progress at school because she was secure in her own identity and open to children from other cultural groups. Her positive attitude to school work is shown in her regular attendance at the weekly Samoan/Pacific Islands homework support sessions at school.

\section{Parents' perceptions of transition to school}

Despite language difficulties in the early years of primary school, Maxine's parents have no worries about the education of their child as they are receiving excellent reports from the school. They are pleased with the fluency with which she still uses the Samoan language in her speech although this acknowledges the important role Maxine is now playing in her education and socialization with other children.

\section{Other significant information}

Maxine writes comfortably in Samoan. When mixing with her non-Samoan speaking friends. she converses with them fluently in the English language. She moves from Samoan to English with ease. The aiga (family) still uses Samoan as the language of family discussion and Maxine interacts with her grandparents fluently in that language. 


\subsection{Case Study Six: A Female Student Who Experienced No Samoan Language in School}

Sia is a six-year-old female student. She was one of 20 children who experienced Samoan in the home, Aoga Amata, church but not in the primary school. This section discusses in greater details of Sia's progress in education.

\section{Family background and home environment}

Sia is the oldest child in the family of three. She lives with her parents and younger sisters in Brooklyn where she attends one of the primary schools there. She communicates with her family in two languages, Samoan and English.

The parents sent her to Aoga Amata for one and a half years in Palmerston North, and again to an Aoga Amata in Newtown when the family shifted to Wellington. The parents sent both their older children to Aoga Amata because the fees were cheaper there than at other early childhood centres. They also wanted their children's first educational experiences to be in Samoan and reflecting Samoan cultural values.

Sia's parents were born in New Zealand. the father in Wellington and the mother in Whangarei. There are seven people in the household. four adults and three children. The children speak both English and Samoan at home but the adults converse in the Samoan language only. The father works as a sales manager, the mother is a registered nurse, and, in the evenings, they both help Sia with her school homework.

\section{Aoga Amata experience}

Sia knew how to write her christian name and surname before she lefi Aoga Amata. She could count up to 10. name colours in Samoan, but she was uncertain in ordering objects by size and was not able to join sets and name them. Although Sia spoke Samoan and English at home, she seldom used English at the Anga Amata. 


\section{Primary school experience}

Sia attends one of the Brooklyn primary schools where she enjoys art, reading, writing, printing, and Physical Education. There is no Samoan language taught at the school, but Sia said that she would have attended a Samoan language class had there been one established there. Now she speaks more English at school than Samoan.

The total school roll was 370 pupils, only 10 were Samoan children. When asked about the lack of provision for the Samoan language the school principal commented:

There is insufficient number of Samoan children to justifi. additional funding that would be needed to provide Samoan as a language option.

\section{Provision of Samoan Language}

As there was no provision for using Samoan in the new entrant's class. Sia found it really difficult to settle at first into the new environment. Her present teacher provided the following assessments for Sia's progress in the various areas of the curriculum:

Table 5I Sia's subject assessment

\begin{tabular}{|c|c|c|c|}
\hline Subjects & Language & Phys Ed. & Story Writing \\
\hline Assessment & Unsatisfactory Unsatisfactory Unsatisfactory & Satisfactory & Unsatisfactory \\
\hline
\end{tabular}

Sia's attendance was rated "excellent" and her health, "satisfactory". For her overall performance the teacher rated her as outlined in Table $5 \mathrm{~J}$ below:

\section{Table 5.J Sia's overall assessment of development}

\begin{tabular}{|c|c|c|c|}
\hline Area of Development & Aciademic & Social & Bchaviour \\
\hline Assessment & $\begin{array}{l}\text { Secms lo he hehind others } \\
\text { and not progressing } \\
\text { quickly }\end{array}$ & Now comlident and happ! & Ohedicm and helplui \\
\hline
\end{tabular}




\section{Teacher's perceptions of the transition to school}

As mentioned in the previous section, the teacher found Sia's progress as to be behind that of other students. The teacher commented that Sia appeared withdrawn, insecure and to have a short attention span. In fact this was the only child of the twenty students in the study where a teacher perceived that the Aogat Amata experience had not appeared to help a child in the transition to school.

When the teacher was asked about the ways they dealt with the child, she said, "I encouraged her to join in, lots of security, encouraged to participate and take risks, praise".

The principal did not think that the Samoan language should be taught at the school, as there were insufficient numbers of Samoan students to warrant the provision. He added that the school had to look carefully at how it could ease the transition for Aoga Amatia children within current resource and funding allocation.

\section{Parents' perceptions of Aoga Amata and the transition to school}

The parents recalled that Sia was scared and refused to cooperate when she was first taken to Aoga Amata. When she was five and was taken to her new primary school she was again scared. There were no other children from the Aoga Amata at the school, so Sia was fearful of the unknown.

In Aoga Amata, Sia had learnt the Samoan alphabet and was able to recite it well and she could recognise some of the letters. She had learnt how to write her first name but could only recognise some of the letters of her surname. The father said,

Sia learnt to respect others. Enjoyed singing the songs she learnt from Aoga Amata but she felt very tired and grumpy at the end of the day due to no rest time at Aoga Amata.

The acquisition of English at school did not appear a problem for Siat as she spoke both English and Samoan at home. However, in terms of what the school should do to further assist the education of the students. the mother added, 
Schools should practice more oral skills. Primary school seems to have a lot of time spent where the child stands up and tells news. The older children should be encouraged in writing and maths skills. Seem to expect the children to know some basics before beginning primary school.

As their comment indicates, the parents have found time to see their child at school. Although the parents appeared to be happy with the education of their child, this assessment was in contrast with the concerns expressed by the teacher over the slow progress that their child is showing in school.

\section{Other significant information}

Because the teacher was concerned at the slow progress that Sia was showing, she felt diffident about assessing her work for the researcher.

\section{$5.8 \quad$ Summary and Discussion}

CASE ONE and CASE TWO present data on children who attended primary schools which provided for the Samoan language. These children appeared to make good progress and adapted well to their new school environment, because they had no difficulty in the in itial language of instruction. Another possible explanation for CASE ONE success was the existence of a Samoan teacher in the school who was able to relate well on a one-toone basis to the learning needs of this child. The parents also contributed extremely well in supporting their child's early education. CASE TWO's success was definitely the continuity of the provision of Samoan language, the existence of a Samoan teacher and again the support from the mother who is also a teacher. This supports the study by Dicke. (1998) who stated that:

In the school curriculum there was contimuity of skills and understandings about reading and writing in their home language and these are a valuable foundation for learning to read and write in English.

In contrast the children who attended primary schools (CASES THREE and FOUR) that had no provision for the Samoan language found the transition difficult because the 
language of instruction was new and they had difficulty understanding it. The challenge of developing literacy in a language the children were not accustomed to using; slowed progress and introduced the children to failure at an early stage in their education.

All the parents in the study supported the establishment of Samoan language classes in primary schools especially as there are increasing numbers of children receiving their early education in Aoga Amata. A second reason was the realization among parents that they maty need help to maintain Samoan through the school providing an educational role for Samoan.

CASE FIVE emphasizes the important contribution of the home and community in the language maintenance of children. In particular, the composition of the household can naturally set the language policy of the home. Where grandparents are important caregivers, Samoan becomes the natural language of interaction. The importance of family attitudes towards the use of Samoan was shown by Fairbairn-Dunlop's (1984) study. Seventy-eight percent of the children in her sample of 40 Wellington Samoan families, spoke Samoan fluently simply because the parents were fluent in the Mother Tongue, and there was high use of the Mother Tongue at home and a strong social organisation. The child in this case study has the strong support of the grandparents and her parents who set rules that Samoan is the only language to he spoken once they enter the home. Their church community also encourages the use of Samoan language in all activities.

CASE SIX draws attention to the individual differences of children and their unique needs in managing the transition for early childhood centres to primary schooling.

Practical issues of roll size and funding appeared to be the key factors, which contribute to decisions not to provide Samoan language classes in primary schools.

Non-provision of Samoan language in primary schools where a high proportion of Samoan speaking children attend, makes the reseatrcher wonder about the issuc of equity here. The provision of funding to all curriculum subjects in New Zealand education should be equal. The Samoan Language Syllabus (Taicala) is now implemented in schools and therefore funding should be made available to establish the teaching of Samoan in 
schools where Samoan speaking students attend.

As a Samoan researcher I endorse the description of one of the essential learning areas as that of 'Language and Languages' in the New Zealand National Curriculum Framework. Within that section the following statement provides for Pacific Islands languages to be taught (p.10):

Students whose mother tongue is a Pacific Islands language or another community language will have the opportunity to develop and use their own language as an integral part of their schooling. The nature of language programmes will be decided by the schools in response to local community needs and initiatives.

There was general awareness of the difficulties that might be experienced by children with limited proficiency in English adjusted to English classrooms, but the situation was being seen as part of the range of individual differences that the schools had to respond to within current funding and staffing levels.

The next chapter will outline additional comments on the recommendiations and policies that should be in operation for language and school transition issues. 


\section{CHAPTER SIX}

\section{CONCLUSION}

\section{Ua taunuu nei i le mutaaga o le galuega}

The task is accomplished.

\subsection{Introduction}

This final chapter presents a summary of the main findings from the interviews (6.2) followed by the main finding from case studies (6.3). The next section (6.4) reports the conclusions and (6.5) discusses the main limitations of the present study followed by the implications for transition programmes (6.6). Section (6.7) outlines the implications for future research and the final section (6.8) provides some concluding thoughts from the researcher.

Perceptions were gathered from a sample of parents $(n=39)$ teachers $(n=14)$, principals $(n=14)$, and children $(n=20)$ concerning the children's transition from Aoga Amata programmes to junior class programmes in primary schools. Secondary aims included the description of how parents viewed the nature and the quality of Aoga Amata programmes, and how teachers viewed Samoan language maintenance issues.

Children were asked to reflect on their Aoga Amata experience and then engage in performance tasks that provided an opportunity to gauge spoken proficiency in Samoan. Both general survey data and case study data were gathered and 
interpreted in terms of recent research on continuity in education and the bilingual development of young children.

\subsection{Main Findings from the Interviews}

Five topics were addressed in the study: coping with the transition to school; the impact of transition practices on children; the perceived quality of Aoga Amata programmes; teacher perceptions of Aoga Amata children; and school provisions for language maintenance. The perceptions obtained from the stakeholders during the interviews are summarised below.

\section{Coping with the transition}

The way Aoga Amata children coped with the transition to primary school depended on the way issues of continuity were addressed by the school and the families concerned. The main strategies used by schools to address continuity include the provision of a bilingual programme; (ii) the provision of inclass language support through various measures; (iii) the provision of adjunct programmes; and (iv) or by displacing the responsibility for continuity onto neighbouring schools, parents, and even onto the Aoga Amata movement itself.

Only one of the fourteen receiving schools specifically addressed the continuity of educational experiences. This school employed a native speaker of Samoan in the Junior school and established a Samoan - English bilingual programme. One consequence of the bilingual provision was that all children interviewed from this school were able to interact with the Samoan researcher in Samoan throughout the interviews and during the performance tasks.

Another school used a native speaker of Samoan in the receiving class within an English medium programme. This arrangement enabled one element of continuity to be- present. Children from the Aoga Amata could converse with the teacher in Samoan during activities. Samoan was used on these occasions as a language of 
explanation and control. Samoan was also used in interaction with the children's parents.

The remaining twelve schools either employed expedient arrangements or did not specifically address the continuity issue. For example, one school used a nonteaching member of the school staff to clarify information with parents and on occasions with a child. Two schools used Samoan speaking children from other classes to be with the new entrant for one or two days during the initial transition period. Parents were also encouraged by some schools to remain with their children during the first few days in the new schools.

At a second level of analysis, schools addressed the issue of continuity through adjust programmes, such as incorporating culturally relevant units of work into the curriculum (three schools); a Samoan language programme in the middle school which operated once a month (one school); and through the establishment of Polynesian cultural clubs (four schools).

Language maintenance is only one element in the continuity between early childhood education, the family, and the school. The nature of the contact between parents and the school, and the type of curriculum experienced by children are two additional elements. In the present study, parents were able to interact with staff at the Aoga Amata on a daily basis both socially and professionally as they came to pick up their children. With the exception of the bilingual class, this situation changed dramatically for many parents when children began primary school. Most parents collected their children by waiting outside the class or even the school without the informal social interaction with their children's teacher.

Only one school directly fostered continuity of the curriculum. In this school (with an Aoga Amata on the school grounds), there was professional contact between the Aoga Amata teachers and the teacher of the bilingual class. The remaining schools did not report any professional contact with the Aoga Amata in their districts. The 
lack of administrative coordination was seen in the general "absence of records" passing between Aoga Amata and schools.

\section{Impact on children}

Children survive arrangements that from many perspectives are less than ideal. But they do so at a cost. For example, Aoga Amata children who go into English only programmes mark time in their literacy development as proficiency in English is established. On average, the children in the present study had received two years of early literacy development in Samoan. In the bilingual programme, literacy in Samoan continued for a further two years as English literacy was established. In such a case, the pedagogical problem was for English literacy to "catch up" to a continually expanding Samoan literacy. In contrast, in English-only programmes, literacy in English began without the expansion of Samoan literacy, effectively "losing" two years of potential literacy development.

Eleven of the fourteen teachers reported that English language development and literacy in English developed quickly in Aoga Amata children. This observation, however, should not be used as a justification for discontinuing Samoan as a language for learning in education. It is the view of the researcher that up to two years of literacy development was lost when Samoan was discontinued as the language of instruction.

Security in cultural identity, and positive concepts of self efficacy were noticed in Aoga Amata children by almost all of the parents, teachers and principals, thereby suggesting that these characteristics were tangible outcomes of the Aoga Amata experience.

\section{Aoga Amata programmes}

Parents were conservative yet critical in their views of the curriculum that their children were experiencing in an Aoga Amata. The need to expose children to Satmoan cultural values, the importance of organisation in the curriculum, and an 
expectation that children would progress in literacy and numeracy, together shaped the comments that parents made about Aoga Amata programmes.

The most frequently cited reason for sending children to an Aoga Amata was "to learn the culture and maintain the Samoan language". However, parents usually had more than one reason for sending their children to Aoga Amata.

\section{Table 6A Multiple reasons for sending children to Aoga Amata}

\begin{tabular}{|l|c|}
\hline \multicolumn{1}{|c|}{ Reasons for sending children to Aoga Amata } & $\begin{array}{l}\text { Number } \\
\text { of parents ( } \mathrm{n}=39)\end{array}$ \\
\hline To learn the culture and maintain the Samoan Language & 38 \\
It is cheaper than other early childhood services & 14 \\
To support church activities & 10 \\
Close to our home & 8 \\
I teach there & 2 \\
Grandmother teaches there & 2 \\
To learn the heritage language of the father & 1 \\
To socialise with other children as she is the only child in the & 2 \\
\hline
\end{tabular}

Typical of the critical views about the organisation of the curriculum was a comment about the "Lack of organised programmes in the afternoon sessions, where the Aoga Amata catered more for older children. For artwork, teachers and parents did most of the children's colouring and painting. Lack of discipline, children kept running around indoors". Three parents suggested that a more organised programme would be beneficial, and even raised the issue of the need for more qualified and experienced staff.

It should be remembered that the observations made by the parents in the sample referred to an early period in the Aoga Amata movement. Considerable professional effort has been spent in enhancing the quality of Aoga Amata programmes, both through the use of national curriculum documents (Te Whariki and the Taiala) and through the diversification of qualification pathways. Teacher education courses are 
available through the Aoga Amata Training Institute, as well as through colleges of education, polytechnics, and universities.

In principle, licensed Aoga Amata should have little difficulty in obtaining professional assistance for establishing continuity in the curriculum with their local primary schools, apart from the language of instruction issue.

\section{Teacher perceptions}

Teachers generally perceived the Aoga Amata experience as helpful in educational development of children. Compared to children who attended other early childhood educational centres, or remained at home, children who had attended an Aoga Amata programme were perceived by ten of the fourteen teachers as having more developed literacy, numeracy, and social skills. The remaining teachers were neutral on this issue. In the latter cases, pupils came from a variety of early childhood education centres and the four teachers could perceive little difference, between Aoga Amata children and children from other services.

On occasions, teacher perceptions were confounded with language issues. The competency of Aoga Amata children was sometimes viewed as being compromised by lack of English language proficiency. The child is competent but she doesn't take' purt in discussion. In such cases, the teachers appeared to be overlooking the fact that it was not the child's fault that the language of instruction has changed.

All of the fourteen teachers specifically emphasized the lack of records kept for the children's progress. This would assist actual placement of children in their right class levels when moved to primary schools.

\section{Language maintenance}

Schools varied in the position they took on language maintenance and on the actions that they were prepared to take. Lack of funding, lack of trained Samoan teachers. and the number of first languages spoken at the school, were frequently cited as 
reasons for English only programmes. The view that the school's cultural activities were appropriate and sufficient was additional reasons given for an absence of language maintenance.

The factors constraining provisions for language maintenance in school policies were objectively true. Some class rolls contained children from five or more different language backgrounds. In most schools there were no native speakers of Samoan on the staff. The Samoan parents of one school in fact wanted English-only programmes. In order to address such issues for Samoan children, new partnerships will need to be formed.

\subsection{Main Findings from Case Studies}

A summary of the results of the six case studies (see chapter 5) is presented in this section. The six case studies complemented the interview data by tracing the consequences of attending an Aoga Amata and then being received into a primary school with particular transition arrangements and particular views, on the language maintenance issue.

If we accept the qualitative assessments by teachers as a basis for making a judgement about particular transition arrangements, then continuity of curriculum and language of instruction would seem to be the most successful of the arrangements (case studies one and $(w 0)$. Here the wo children were members of the bilingual class that had a close association with the Aoga Amata. The use of the Taiala and Te Whariki in the Aoga Amata, as well as the frequent contacts with the Junior class teacher ensured continuity in the educational activities that the children were experiencing during the transition period.

When children move from an Aoga Amata to a primary school without continued language support, there was agreement among the child's parents, teachers. and principals that the child's progress was compromised, at least in the early stages of the transition (case studies three and four). These children, however, were seen to 
overcome the disadvantage of the language switch relatively quickly, suggesting that continuity in the curriculum was at least beneficial to the children.

Case study five demonstrated that certain home factors might be important for language maintenance when the child is being educated in an English-only programme. The importance of the role of grandparents and the church were underlined in this case study, as was the importance of having a home language policy observed by both parents.

The disappointing progress made by the child in case study six, was attributed by the parents to the number of geographical shifts that the family had been required to make.

From the case studies, it would appear that some language continuity is necessary for the full benefits of an Aoga Amata experience to be achieved. Where language continuity cannot be provided at school, both curriculum continuity and home language policies may be sufficient for ensuring the regular educational development of Aoga Amata children.

\subsection{Conclusions}

Based on the results of the interviews and the case studies a number of conclusions can be reached:

1. Schools with English-only solutions to the transition requirements of Aoga Amata children may not be properly appreciating the importance of language continuity in the education of bilingual children. The one school with a bilingual solution to the transition problem provides an example of what could be achieved given the will of the community and the policy initiative of the school. Where English-only solutions were in place, the importance of language continuity appeared to be devalued in the education of Anga Amati graduates. 
2. Parents, teachers, and principals viewed the transition from different perspectives. Parents generally saw Samoan language development as an important part of their children's education and firmly believed that the Aoga Amata experience was a better option for their children than attendance at other kinds of early childhood centres. Teachers in English-only programmes, however, saw little difference between Aoga Amata children and kindergarten children, showing that curriculum continuity was uppermost in their minds. In such schools, principals would usually advance administrative reasons as to why language continuity could not be fully achieved in their programmes. In only one school was there convergence of views as the importance of language continuity.

3. Language maintenance can proceed through many pathways. However, in the present study, only one school was included in the pathway. For Aoga Amata children attending the thirteen other schools surveyed, the pathway was confined to the children's homes, networks in the community, and the church.

4. If schools are to consider seriously the role of language continuity in the transition arrangements for Aoga Amata children, there will need to be new initiatives in the resourcing of schools, the training of staff, and the development of school language policies. Only one of the fourteen schools in the present study appeared to take full advantage of the possibilities under present regulations and teacher training opportunities.

5. The survey showed that both administrative and professional continuity was not in place in the majority of the schools surveyed. Clearly this is a matter of urgency if the situation is still existing. Both the Aoga Amata and the primary school have responsibilities for the coordination of the education of 
children who choose to attend an early childhood education service in their home language.

\subsection{Limitations}

It is important to mention that the results of the study were obtained from a small sample of primary schools (n-14) and children (n-20) and therefore we ought to be very cautious about making generalisations based on the results.

Every attempt was made to use culturally sensitive approaches to data collection. However, families and school staff were busy and had many calls on their time. Cultural events such as weddings, birthday celebrations, funerals and overseas travel frequently disrupted the flow of arrangements for interviewing people. On occasions, interviews became questionnaires, which in turn required clarification. These were not serious issues as the data involved recollecting experiences of the transition to primary school.

\subsection{Implications for Transition Programmes}

Based on the perceptions of the various stakeholders in the present study, there are a number of initiatives that could ease the transition from Aoga Amata to primary school for Samoan children.

First there is a need to develop a goal for transition practices that is shared by staff at the Aoga Amata, parents, and teachers at the receiving school. In setting the goals, there will need to be a shared understanding of what is meant by transition to school and an awareness of the costs of not achieving continuity of experiences in a child's life. The present study showed a low emphasis was placed on transition with only one school having a formal progtamme for maintaining the child's home language for education. 
Second, an agreed set of strategies to ensure continuity should be mandated at least at the Aoga Amata and school community level. Several domains of transition will need attention in the mandate: administrative coordination, curriculum continuity, parent involvement, language maintenance, professional development, and coordination among support services. Of particular importance is an articulated curriculum from Aoga Amata through at least to the end of year two in the junior school, a coherent plan for maintaining home languages, and fresh initiatives for achieving parental involvement in a child's education.

Third, incentive schemes are needed to encourage schools, Aoga Amata staff, and parents to focus on transition issues. At the national level, funding may be needed to establish and monitor transition standards. The facilitating conditions for continuity are reasonably well understood - shared vision, strong local partnership between Aoga Amata and the school, and patience with developmental processes (Kagan and Newman 1998:371). Less well-understood are how to deal with factors constraining transition activity such as divergent polices, traditional school practices, and difficulties in establishing working partnerships among services.

Four, reconsideration must be given to the question of who is responsible for initiating policy and practices for improving the continuity of educational experiences for Samoan children. A natural forum for creating policy would be the Fatalapotopotoga mo le Aoaoina o le Gagana Samoa i Aotearoa (FAGASA, the National Organisation for the Teaching and Learning of the Samoan Language in Aotearoa).

At the regional level, the Sosaiete a Aoga Amata Samoa I Aotearoa (SAASIA, the Samoan Aoga Amata Association in Aotearoa) may need to initiate professional development programmes that focus specifically on continuity issues. There is perhaps an important role for Aoga Amata staff, who have Diplomas in teaching, to be working in junior classes on a nationally agreed transition programme. 


\subsection{Implications for Future Research}

The research has tried to assess the value of the Aoga Amata experience within the overall perspective of achieving continuity in a child's early education. The national planning documents and papers prepared by members of the Aoga Amata association have given a good indication of the objectives of the various Aoga Amata programmes. Children are expected to be secure in Samoan, be making developmentally appropriate progress in the various areas of human development, and be ready for the next phase of their education. The extent to which these objectives were achieved within the children that were sampled in the present study was a matter of opinion. Future research would need to keep longitudinal information in several cohorts of children as they pass through the Aoga Amata and progress in their primary education. These children will need to be compared with a matched group of children who attend other services or who remain at home. Again the development of the comparison children will need to be studied across a number of years.

The language maintenance issue will need to be examined separately and with appropriate comparison groups. The complex situational nature of bilingualism calls for comprehensive data collection that monitors home and community variables as well as school factors in language development. Appropriate tests of Samoan proficiency will need to be developed and calibrated against the language development of children in Samoa.

Overall, the study showed that people had limited understanding of the notions of "transitions" and "continuity" in the education of their children. Future studies could well start by exploring the perception of these terms and tracing the effects thall a focus on continuity might have. The vision and the strategies would then hecome the variables of particular interest. 


\subsection{Concluding Thoughts}

A lack of an agreed understanding of what is necessary for successful transition was the main issue encountered in the study. Stakeholders in the children's education were not overtly focused on the need to have policy, strategies and standards to guide continuity, between home, Aogal Amata, school and community. Part of the issue is the language (Samoan or English) in which discussions are taking place. For this reason, a version of the present research will be prepared in Samoan in the expectation that it will prompt constructive analysis by stakeholders in the Aoga Amata movement.

Early childhood educational provisions are at the discretion of parents. It is therefore important that choices are made for reasons of philosophy, quality and value. Choices should not be constrained by inequalities of funding, training, and alignment with primary education. There are a number of agencies already working in the area of quality assurance. These include the Early Childhood Development Unit, the Ministry of Education through professional development contracts. professional associations such as SAASIA (Sosaiete a Aoga Amata Samoa I Aotearoa), and FAGASA (Faalapotopotoga o le Aoaoina o le Gagana Samoa I Aotearoa), and Colleges of Education. There is therefore potential for a number of policy initiatives to be trialled for improving the transition practices lor Aoga Amata children.

The parents interviewed in the study and the children and their teachers thought carefully about the questions put to them. The care and reflection in their replies placed children at the centre of their concern and provided for the rescarcher a vision of a better education for Samoan speaking children.

The study had enabled me to utilise use of cultural methods in the collection of data and the conducting of interview procedures. As a Samoan researcher, I felt comfortable in carrying out this research in the Samoan way, which showed tangihle 
outcomes of participants' information as required to respond to the key research questions. For future researches, I would be inclined to carry out the same methods again, but depending on the ethnicity background of the stakeholders.

\section{Equity issues}

Having read about the success of Te Kohanga Reo Movement, and the Statistics from the Ministry of Education (1998) which outline the fast increase of Pacific Islands children's enrolment in early childhood education services, it makes me wonder about how the government allocates funds to the various government departments. For sure, the education sector does not seem to have equal distribution or allocation of funds to the areas, which are crying out loud for resources. 


\section{APPENDICES}

Appendix A1 A sample of interview questions for parents

Appendix A2 Interview Schedule for Children

Appendix A3 A Copy of the Interview Questions for Principles

Appendix A4 A Copy of the Interview Questions for Teachers

Appendix B1 A Sample letter to and Consent form for Parents

Appendix B2 A Sample letter to Principles

Appendix C A Copy of the Performance Tasks for Children 


\section{APPENDIX A1: A sample of interview questions for parents}

\section{Please answer all of the following questions}

Name of child Date of Birth

Place of Birth Place of child in family

If born in Western Samoa, when did he/she arrive in NZ?

Name of parents:

Father's name and surname

Place of birth

If born in Western Samoa when did you arrive in NZ?

Age group:20 - 25, 26 - 30, $31-35,36$ - 40, 41 - 45, 46 - 50, $51-55,56-60,61-65,66-70$.

Occupation:

Mother's name and surname

Place of birth

If born in Western Samoa, when did you arrive in NZ?

Age group: 20 - 25, 26 - 30, 31 - 35, 36 - 40, 41 - 45, 46 - 50, $51-55,56-60,61-65,66-70$.

Occupation

A'oga Amata Experience:

1. Why did you send your child to A'oga Amata? Aisea na e faaa'ogaina ai lou alo i le A'oga Amata?

2. What did you observe in his/her first few days in A'oga Amata? scared happy..... refused to cooperate.

O le a la oulua silafia i ona aso muamua i le A.Amata?

fefe fiafia musu

3. How many years was she/he at A.Amata? E fia tausaga sa i ai o ia i le A. Amata?

4. What skills did you observe in ........before she/he left A. Amata? O a tomai na lua iloa ia......... a o le'i uma lana A.Amata?

a. could recite the Samoan alphabet. 
b. could recognise some letters of the alphabet.

c. could write her/his name and surname

d. could write only first name.

e. could write some letters of name and surname

f. could count numbers from $1-10,--50,--60 .----100$.

g. could recognise numerals 1 - 10,----50, ----60----100.

h. could read 2 letter words,......., a few words.

i. none of the above

5. a. What are the positive things that you observe in the education of your child while at Aoga Amata?

O a ni mea lelei na maitauina i le a'oa'oina o lou alo a o i ai i le A. Amata?

b. What are the negative things that you observe in the education of your child while at A. Amata?

O a ni mea le lelei na e maitauina i le a'oa'oina o lou alo i a o i ai i le A. Amata?

6. Were you happy with the education your child had from A. Amata? Sa e fiafia i le a'oa'oga na maua mai e lou alo mai i le A.Amata? Yes No why?

7. Were there any other of your children who did not attend A. Amata? E iai nisi o lua alo e le'i ulufale i le A.Amata? Aisea? Yes/Ioe No/Leai Why/Aisea?

8. What differences did you observe in them in comparison with and her/his school performance?

O a ni eseesega na lua maitauina ia i latou pe a faatusatusa ia i lona tulaga faa le a'oa'oga?

\section{School Environment:}


9. How did she/he find school in her/his first few days in the Primary school?Why? Na faapefea lona ulufale atu i totonu o lana a'oga fou? school)

fefe(scared).........fiafia(happy) ___ musu e alu i le a'oga(refused to $g$ o to

10.a. Did.............. find the English language difficult to understand? Yes...............,No..............Why?

Na faigata ona malamalama ......... i le gagana Peretania?

Ioe Aisea?

b. If yes to No.10, how was ........getting help in his subjects?

Afai o le Ioe le tali i le numera 10, na faapefea ona maua le fesoasoani o mo ana mataupu?

From his Samoan friends/Mai ana uo Samoa.

From his older sister/brother in the same classroom/Mai ona tei matutua e i le vasega e tasi

From the Samoan teacher in the school/Mai le faiaoga Samoa e i le a'oga

c. If yes to number 10 , how did you find out about this difficulty?

Teacher school

in his classroom other. , your daughter/son Your observation

Afai e Ioe i le numera 10, na faapefea ona oulua iloa le faafitauli?

faia'oga. a'oga lo lua alo o se isi........

d. If No to number 10 , how did you find out about it?

Afai e Leai i le numera 10, na faapefea ona oulua ?

11 What subjects do you know she/he enjoys most in school?

O a mataupu e te lua silafia e fiafia tele $i$ ai $o$ ia i le a'oga?

Maths Reading Story writing.

P.E. Science Spelling Language......

12. What subjects do you think........ does not like at school $\mathbf{O}$ a mataupu e le fiafia i ai ........ i le a'oga?

Maths......... Reading......... Story writing.

P.E............ Science Spelling Language 


\section{Home environment:}

13. Number of people in the household

Le numera o tagata o le aiga

Total number of adults/aofa'i o tagata matutua. number of children/aofa'i o tamaiti.

14.a. Language of communication with ....... at home?

Le gagana e fesoota'i ai outou ma.......i le aiga?

Samoan

English

Both..

Other.

b. What language do adults communicate with .... at home?

O le a le gagana e fesoota'i ai ....... ma isi tagata matutua o lo outou aiga?

Samoan.

English.

Both.

Other.

c. What language do the students/children communicate with at home?

$O$ le a le gagana e fesoota'i ai ....... ma tamaiti o lo outou aiga?

Samoan English Both. Other.

d. What language does .......use at church?

$\mathrm{O}$ le a le gagana e faaaga e ...... pe a alu i le lotu?

Samoan......... English.........Both............ Other.

e. If the Samoan language is not taught in your child's school, would you like it to be? Afai e le o a'oa'oina le gagana Samoa i le a'oga o loo i i ai lo lua alo, e te lua finagalo e tatau ona a'oa'oina ai?

Yes/Ioe No/Leai.

why/aisea?.

f. Do you want your child to maintain her/his Samoan language when he/she becomes an adult?

Yes. No.

Comment.

15. What are the things that she/he enjoys doing at home?

$O$ a mea e fiafia $i$ ai $o$ ia e fai i le aiga?

play/taalo watch t.v./matamata T.V.

tidy the house/teu le fale wash dishes/fufulu ipu

reading/faitau tusi writing/ tusitusi

school homework/fai mea a'oga

play at the park/ tafao i le paka

shooping/faatau i le faleoloa

16. Does she/he do any homework for school at home or in the library?

E fai ni ana galuega mo le a'oga i totonu o le aiga?

Home/aiga Faletusi/Library Isi nofoaga/other places

17. How much time a week does she/he spend on his homework? 
O le a le taimi o le vaiaso e faaluina mo ana galuega o le a'oga?

18. Does she/he come to you for help if she/he needs any about her/his school work? If No, why?

E fesili atu ia te oe pe a ia mana'omia se fesoasoani i mea a'oga?

Yes/Ioe........., No/Leai.........

Why/Aisea?

19. Does she/he ask for help about her/his school work from her/his older brothers and sisters?

$E$ fesili i ona uso ma tuafafine/tuagane matutua mo se fesoasoani e fia maua mo ana mea a'oga?

20. Do you have any worries about her/his education?

$\mathrm{O}$ i ai ni popolega ia te oulua e uiga i lona a'oa'oina?

Yes/Ioe........ No/Leai.....

If yes, what are they? why?

Afai $\mathrm{e}$ i ai o a la ia popolega? Aisea?

21. What are the things that you do at home to help her/him about her/his education?

O a mea e te lua faia $\mathrm{i}$ totonu o le aiga e fesoasoani ai ia i lona a'oa'oga?

22. Are you happy with your child's progress in school?

O lua fiafia i le gasologa o le taumafai o lo lua alo i le a'oga?

Yes/Ioe...... No/Leai.

Comment/faamatala mai.

23. Are there things which you think the school should have done to further assist the education of your child?

$\mathrm{E}$ i ai ni mea e te lua finagalo e tatau ona fai e le aoga e fesoasoani atili ai i le a'oa'oga o lo lua alo?

Yes/Ioe........, No/leai. 
24. Any other comment about yourself which I have not yet asked? $\mathrm{E}$ i ai se mea o lua fia saunoa mai ai, ou te le i fesili atu ai? Yes/Ioe......... No/Leai.

Comment/Faamatala

Thank you very much for your cooperation in this research Faamalo faafetai atu i lo oulua faapalepale i lenei galuega.

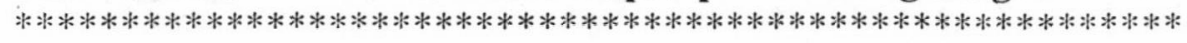




\section{APPENDIX A2: Interview schedule for children}

Name and surname

Date of birth

Sex

School

If born in Samoa what year did you arrive in New Zealand?

\section{AOGA AMATA EXPERIENCE:}

At 5 yrs old were you able to:

$1 \quad$ write your name and surname? Yes No Not sure

2 spell your name and surname? Yes No If not how many letters of your name could you write?

3 count numbers up to 10? 50? 100? More?

4 name colours in Samoan? Yes No Some if yes what are they?

5 order objects in sizes? Yes No Not sure

6 add simple additions? Yes No Not sure

$7 \quad$ understand simple tasks? Yes No

Not sure

\section{LANGUAGE USE:}

8 What language do you hear and speak at home? English Both Other

9 What language do you hear and speak in church? Samoan English Both Other

10 What language do you hear and speak at school now? Samoan English Both Other

11 How often do you use Samoan language? everyday often not at all

Where? Home church school 
12. Did you speak Samoan language only before you attended primary school? Yes. No Not sure

\section{SCHOOL CURRICULUM:}

13 What subjects do you like best in school?

14 What subjects don't you like in school?

15 Is Samoan language one of the subjects taught in your school? Yes No

16 If yes, do you attend that class? Yes No

17. If the Samoan language is not taught in your school, would you like it to be? Yes No

18. What language do you use more often now in school?

Samoan English 50/50 Samoan/English

19. Do you write in Samoan? Yes Not very well No Quite well 


\section{APPENDIX A3: A copy of the interview questions for principals}

\section{SCHOOL ORGANISATION}

la Number of students in the school

b Number of teaching staff

2. Number of Samoan students

3. Number of Samoan staff members

4.a. If the Samoan language is taught in your school, how one hour daily one hour monthly one hour weekly Once a term

often is it taught?

b. Do you think the time allocated for the teaching of Samoan language is sufficient? Why?

Yes No Reason

5. What is the programme content ?

6. If the Samoan language is not one of the subjects taught in your school, do you think it should be taught? Why? Yes No Reason

7. Do you have any records of his developments and skills from $\mathrm{A}^{\prime}$ oga Amata? Yes No

9. If No, why is it important for you to obtain records?

10.

Any' further comments.

Thank you for your help in this research. 


\section{APPENDIX A4: A copy of the interview questions for teachers.}

1. How is Not well coping with the language of instructions?

quite well satisfactory very well not satisfactory excellent

2. If 's language is poor, how is she/he getting help? ESL tuition peer support

Teacher's help

Other

3. If the child is strong with his/her Samoan language, is he/she continuing learning it in school? How? (tick the appropriate answer below) By attending Samoan language class in the school depending on the parents to teach it church other

4. How does cope with:

Maths Science Writing Language Maori

Physical Education Spelling Reading Story (write the approriate answer for each subject from the list below).

Excellent, very good, good, satisfactory, unsatisfactory.

5. What is his/her attendance like? (tick the appropriate answer from the box below:) excellent very good good satisfactory unsatisfactory

6. What is her/his health like? (tick the appropriate answer from the box below)

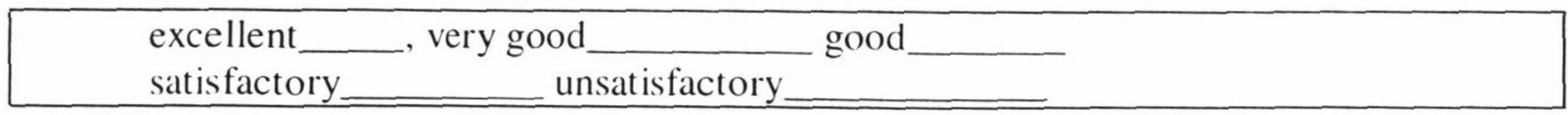

7. What is her/his overall performance like? academic:

social: behaviour:

excellent, very good, good, satisfactory, unsatisfactory. 
8. What are the subjects that she/he works well in? (Primary School children only)

Maths Music Story Writing

Reading Spelling Drama Science

Sports Polynesian Club Other

Secondary school students only:

Maori Music Maths Science

English Typing Drama Sports_ Other

9. What subjects does she/he/ need help in?

Maori Music Maths Science

English Typing Drama Sports_

Other

10. What concerns did you have when .......first arrived from A. Amata?

11. How were these concerns dealt with?

12. Are there any Samoan children in your class who did not attend A.Amata? Yes No

13. If Yes to No.13, did you observe any difference between the two groups in their performance in the classroom?

positively Negatively other

14. Do you think that by attending A. Amata helped him/her in her/his schooling's progress? Yes No

How?

15. Do you see a need of having the Samoan language taught in your school? Yes No Why?

The following questions are about yourself:

16. a. School

b. Teacher's name c. Ethnicity

d. Age group: $20-25.26-30,31-35,36-40,41-45,46-50$, $51-55,56-60,61-65$. 
17. Is there anything you want to comment about

that I have not yet asked?

Thank you for your help in this research. 


\title{
APPENDIX B1: A sample letter to and consent form for parents
}

\author{
11 th May 1996 \\ 33 Beaumaris Crescent \\ Ascot Park \\ Porirua
}

Dear $\mathrm{Mr}$ and $\mathrm{Mrs}$

\section{Su'esu'ega mo tamaiti na a'oa'oina i A'oga Amata}

Ou te faatalofa atu i lau susuga ma le faletua. Malo le soifua maua ma le lagi e mama!

E muamua pea le faafetai ma le faamalo i le tausiga matagofie a lo tatou Atua ua mafai ai ona tatou felogoa'i $i$ laupepa ona o ala o galuega ma a'oa'oga o loo taumafai atu $i$ ai.

Ua ou tusia lenei tusi i le ava ma le faaloalo lava e faailoa atu ai le su'esu'ega o loo o'u faia nei mo tamaiti Samoa. O lenei su'esu'ega e faatatau tonu mo tamaiti na a'oa'oina i le Aoga Amata i le talafatai o Ueligitone atoa. E aofia ai Porirua, Ueligitone ma Hutt Valley. E faatatau tonu fo'i lenei su'esu'ega mo le faailoga o le Master's Degree i le Univesete. O le faamoemoe ina ia mafai ona maua ni faamaumauga i le gasolo i luma o tulaga a'oa'oina o alo a Samoa na amataina mai le Aoga Amata. A e maise o le faamautuina o le a'oa'oina o la tatou gagana Samoa i totonu o falea'oga a Niusila nei.

E le o tele ni faamaumauga tusia i le gasolo i luma o alo ma fanau a Samoa i totonu o a'oa'oga i Niusila nei. O loo i ai fo'i le tele o matua Samoa e le o mamafa lo latou naunau i le a'oa'oina o le Gagana Samoa ona e faapea le mau e le o maua ai ni galuega ma isi lava itu. O lenei fo'i la su'esu'ega o le a taumafai e faamaumauina i gagana e lua ina ia maua ai se silafia o matua e le o lava le silafia o le gagana Peretania, i ni faai'uga o le a maua mai $i$ lenei taumafaiga e faamoemoe atu i ai.

O tali uma e tuuina mai e outou matua, faapea ma faia'oga ma Pule A'oga o le a gata lea i totonu o lenei su'esu'ega e le tusia o outou suafa faalaua'i tele.

O lea la ua ou talosaga atu i le ava ma le faaloalo lava ona e mana'omia lo outou faatagaina o a'u e fesiligia o outou alo ma o latou faiaoga i se talanoaga (interview) mo lenei su'esu'ega. E mana'omia fo'i se taimi e tatou te talanoa ai ma oulua matua.

Faamolemole telefoni mai i le numera 2359091 e talanoaina ai se aso ma se taimi e talafeagai ma o oulua taimi avanoa i le vaiaso lona lua o Iuni.

Faamalo atu le lagolago mai i lenei taumafaiga. Ia faamanuia atu le Atua i lo outou feagai ai ma galuega, le tautuaina o ekalesia, a e maise le feagai ai ma le tausiga o aiga i lenei atunuu.

Soifuaina lo outou mamalu

Le'autuli'ilagi Malaeta F. Sauvao

RESEARCHER. 
Faamolemole saini mai le pepa ua tusia i lalo ona e fia maua la oulua "Ioe" faamauina (tusia) e taliaina lenei su'esu'ega

\section{$\underline{\text { Su'esu'ega (research) mo tamaiti na a'oa'oina i Aoga Amata }}$}

Ua ma fiafia e su'esu'eina la ma tama o

(igoa o lo oulua alo) i totonu o le a'oga, faapea ma ona faia'oga ma le pule a'oga e uiga i lona i ai i le a'oga i soo se mata'upu. Ua ma faatagaina fo'i maka o su'ega o e taga'i i ai le tama'ita'i su'esu'e mo lana sa'iliiliga, ona o se su'esu'ega aoga mo matua ma alo o Samoa i itu tau a'oa'oga.

Ua ma fiafia fo'i e taliina fesili uma e tuuina mai mo i ma'ua e uiga i la ma tama, i le aso o le a talafeagai ai mo i tatou uma.

Faamolemole telefoni mai i le numera 2359091 pe a i ai se fesili e fia malamalama ai e uiga i lenei faamoemoe.

Sainia lou suafa atoa. Aso

Tama/Tina

Faafetai tele atu le lagolago mai i lenei taumafaiga. Ia faamanuia atu le Atua i o outou aiga uma, a e maise o le feagai ai ma galuega.

\section{Soifuaina}

Le'autuli'ilagi Malaeta Sauvao

Researcher

\section{Translation:}

We give our consent for our child to be interviewed and any relevant information regarding her /his progress to be obtained from the school. This is a valuable research for our people and the education of our children.

We are also happy to be interviewed at our place of preference on a date that will suit all of us.

Signed full name Date

Mother/father

Telephone 


\section{APPENDIX B2: A sample letter to principals}

\section{September 1996}

\section{Beaumaris Crescent}

Ascot Park

PORIRUA

\section{Dear Principal,}

\section{Ref: Study of children who attended Aoga Amata (Samoan Language Nests).}

As part of the requirement for the Master's Degree of Education research project at Victoria University of Wellington, I write to ask for your permission and consent for me to come to interview you and the teachers of consent form from the parents will be posted to you. for the purpose of this study. The

Please note that all interviews and information given will be kept strictly confidential and will be used for the purpose of this research only.

There is a lack of research in this particular area, regarding a follow up study of these Aoga Amata graduates. It is anticipated-that the research will be a useful resource for the educational institutions and the Samoan community. The study will be reported bilingually to cater for those Samoan parents who have difficulties in the English language.

I would appreciate it if you contact me regarding date and time that both you and your staff concerned would be available for interview. If you prefer to fill in a copy of the questionnaire instead of a personal interview, then it is attached for your convenience. Should you decide to fill in a questionnaire, then I would appreciate it if it is returned to the above address by the END OF THE WEEK please.

The parents and the child will have personal interviews at their place of residence as requested.

Please ring me on Phone (04) 2359091 day or night if you have any further queries regarding this research.

I trust that you will give this matter your favourable consideration and I look forward to hearing from you soon.

Yours faithfully,

Le'autuli'ilagi Malaeta F. Sauvao

$\underline{\text { Researcher }}$ 


\section{APPENDIX C A copy of the performance tasks for children}

Performance Task sheet

Equipment: cuisenaire rods, coloured counters, favourite books

Simple instructions:

$1 \quad$ Faitau mai laau ia faamolemole (count these rods please)

2 Faasolosolo mai laau ia mai le laitiiti e oo i le lapoa (arrange these rods in sizes)

3 Tuu i totonu /fafo le tusi (put the book inside/outside)

4 Tu i luma o le/tua o le laulau ( stand in front of/ behind of)

5 Ta'u mai lanu o mea ia (tell me the colours of these things/counters)

6 Faitau mai lau tusi lea (read your book to me)

7 Faamatala mai oe ma lo outou aiga (tell me about yourself and your family) 


\section{BIBLIOGRAPHY}

'Aipolo, A. (1989). Profile of Language maintenance and shift of the Tongan community in Wellington. Unpublished M.A. Thesis. Wellington: Victoria University of Wellington.

Barney, D. (1975) Who Goes to School? Wellington: New Zealand Council for Educational Research.

Benton, R. (1986) The Maori Language: From the Treaty of Waitangi to the Waitangi Tribunal. N.Z.C.E.R. Paper prepared for Language Revival \& Maintenance in New Zealand. Today edited W. Hirsch.

Blatchford, P., Battle, S. and Mays, J. (1982) The First Transition. Windsor, Berks: NFER Nelson.

Briggs, F. and Potter, G.K. (1990) Teaching children in the first three years of school. Sydney: Longman.

Bronfenbrenner, U. (1979a) The ecology of human development. Massachusetts: Harvard University Press.

Bronfenbrenner, U. (1979b) Contexts of child rearing: problems and prospects'. American Psychologist Volume 51, pp 5-32.

Burgess, F. (1997) Unpublished paper on the Aoga Amata Movement. A paper presented at the workshop for the OECD Conference in Christchurch.

Carr, M. (1998) Taking Dispositions to School: Keynote address to Seminar on Transition to School. Journal of the Children's Issues Volume 2 No. 1.

Clay, M. (1970) Polynesian Language Skills of Maori and Samoan School Entrants. Polynesian and Pakeha in New Zealand. Volume 2 
Cleave, S, Jowett, S. and Bate, M. (1982) And So To School-A Study of Continuity from Pre-School to Infant School, Windsor, Berks; NFER Nelson.

Clyne, M. (1982). Multilingual Australian, Melbourne: River Seine.

Clyne, M. (1985). Language Maintenance and Language Shift: Some data from Australia. In N. Wolfson and J. Manes (eds). Language of Inequality. The Hague: Mouton.

Cooper, D and Tangaere, P.R. (1994) A Critical Analysis of the Development of Early Childhood education in Aotearoa. In E. Coxon, K. Jenkins, J. Marshall, L. Massey (eds). The Politics of Learning and Teaching in AotearoaNew Zealand. Palmerston North: Dunmore Press

Cullen, J. (1998) Emergent Learners: Making the Transition to School. Journal of the Children's Issues, Volume 2, No.1.

Cummins, J. (1986) Empowering Minority Students: A Framework for Intervention. Harvard Educational Review Volume 56, No 1, pp 18-36.

David, T. (1990) Under Five - Under Educated? Milton Keynes: Open University Press.

Dickie, J. (1998). Emerging Literacy at Home and School: Work presented at Seminar on Transition to School. Journal of the Children's Issues, Volume 2, No.1.

Erickson, F. (1984) School Literacy, Reasoning \& Civility: An Anthropologists Perspective: Review of Educational Research, Winter Volume 54. No. 4, pp 525-546.

Fairbairn-Dunlop, P. (1984) Factors Associated with Language Maintenance: The Samoans in New Zealand. New Zealand Journal of Educational Studies, Volume 20, Number 2.

Fasold, R (1984) The Sociolinguistics of Society. Oxford: Blackwell. 
Fuli, E. (1994) Maori Women in Higher Education: The Educational Experiences of five Maori Women at Victoria University of Wellington.

Giles, H. (ed). Language, Ethnicity and Intergroup Relations. London: Academic Press.

Giles, H., Richard, Y.B. and Donald, M.T. (1977). Towards a theory of language in ethnic group relations. In H. Giles (ed). Language, Ethnicity and Intergroup Relations. London: Academic Press, pp307-348.

Heath, S.B. (1983) Ways with Words: Cambridge: Cambridge University Press.

Hohepa, M.K. (1993). Preferred pedagogies and Language Interactions in Te Kohanga Reo. Monograph No. 13. Auckland : Research Unit for Maori Education, University of Auckland

Holmes, J. (1987) "Providing Support for the Language Learner". In W. Hirsh (1987) Living Languages: Bilingualism \& Community Languages in New Zealand. Auckland: Heinemann.

Holmes, J. (1993) Women's Roles in Promoting Bilingualism, Many Voices 4, February, pp7-11.

Holmes, T. (1998) Transition to School. Journal of the Children's Issues, Volume 2, No. 1

Jamieson, P. (1980) "The pattern of urban language loss". The Australian and New Zealand Journal of Sociology, Volume 16, No.2, pp102 -109.

Jenkins, K. with Ka'ai Tania. (1994) Maori Education: A Cultural Experience and Dilemma for the State- a New Direction for Maori Society In E. Coxon, K. Jenkins, J. Marshall, L. Massey (eds). The Politics of Learning and Teaching in Aotearoa-New Zealand. Palmerston North: Dunmore Press 
Ka'ai, T. (1990) Two Studies of Transitions Socializations of Literacy: and Te Hiringa Taketake: Mai i te Kohanga Reo Ki te Kura Maori Pedagogy: Te Kohanga Reo and the Transition to School. A Report on a Research Project Funded by the Ministry of Education. Maori Research and Development Unit, Education Department, University of Auckland.

Kagan, F.L. and Newman, M.J. (1998) Lessons from three decades of transition research. The Elementary School Journal, Volume 98 No.4. pp 365 - 379.

Katz, L. (1982) Current Topics in Early Childhood Education, Volume IV, [ERIC] Clearing on Elementary and Early Childhood Education. University of Illinois at Urbana-Champaign. New Jersey: Ablex Publishing Corporation,

Katz, L.G. (1984) Contemporary perspectives on the role of mother and teachers. In L.G. Katz. More Talks with Teachers Urbana Illinois. ERIC Clearly House on Elementary and Early Childhood Education, pp 1-27.

Katz, L. G., and Mc Clellan, (1991) The teacher's role in the social development of young children. ERIC Clearinghouse on Elementary and Early Childhood Education.

Kerslake, D. and M.(1987). Faa Samoa In Walter Hirsh (ed) Living Languages: Bilingualism \& Community Languages in New Zealand. Auckland: Heinemann.

Koloto, 'A. H. (1995) Estimation in Tongan Schools. Unpublished PhD Thesis. Hamilton: University of Waikato.

Kroef, A.P.M. (1977) The Use of Language in a Three -Generational Group of Dutch Immigrants in New Zealand. Unpublished M.A Thesis, University of Auckland.

Kulick, D. (1992) Language Shift and Cultural Reproduction: Socialization, Self, and Syncretism in a Papua New Guinea Village.Cambridge University Press. 
Lameta-Tufuga, E. U. (1995) Using Samoan Language for Academic Learning. Unpublished M.A. Thesis. Wellington: Victoria University.

Mara n Foliaki I and Coxon F. (1994) Pacific Islands Education. In E. Coxon. K. 
Ministry of Education (1996) Ko e Ako a e Kakai Pasifika. Pacific Islands Education in Aotearoa, New Zealand Towards the Twenty-first Century. A plan to promote Pacific Islands peoples' success in New Zealand education. Wellington: Ministry of Education.

Ministry of Education. (1997) Education Statistics, News Sheet, Vol.7 No.11.

Morgan, T. (1995) Language Learning in the Home-based Setting, Many Voices, A Journal of New Zealand Settlers and Multicultural Issues, Wellington Learning Media Ltd., Ministry of Education.

Ngan, W. (1987) The maintenance on Chinese language in New Zealand. In Walter Hirsh (ed) (1987) Living Languages: Bilingualism \& Community Languages in New Zealand. Auckland: Heinemann.

OECD (1983) The Education of Minority Groups, An enquiry into problems and practices of fifteen countries.

O'Rourke, M. (1991) Education Gazette, Wellington: Learning Media Ltd, Ministry of Education.

Peters, S. (1997) Facilitating the transition to school: Exploring the concerns of children, parents and teachers. Paper presented at the National Seminar on the Transition to School, Victoria University, November 1997.

Pratt, C. (1985) Transition to school: A shift from development to learning. Australia Journal of Early Childhood 10, 11-16 in Childrenz. Issues, Volume 2 No.1.

Ramey, S.L: and Ramey, C.T. (1994) The Transition to School: Why the first few years matter for a lifetime. Phi Delta Kappan, Volume 76, No.3, pp 194 - 198.

Rata, E. (1989). Kura Kaupapa Maori. PPTA Journal, pp30-32 
Renwick, M. (1984) To School at Five: The transition from home or pre-school to School. Wellington: New Zealand Council of Education Research.

Renwick, M. (1997) Starting School. A guide for parents and caregivers. Wellington: New Zealand Council for Education Research,

Roberts, M (1990) Language Maintenance and Shift and Issues of Language Maintenance Education in a section of Chinese community in Wellington. Unpublished Thesis. Wellington: Victoria University of Wellington.

Robson, S. and Smedley, S. (1996) Education in Early Childhood, First Things First. London David Fulton Publishers Ltd. WCIN 3JX, pp 66-69.

Saipele, N.M. (1994). Proverb of Samoa. Wellington: Bay Typesetters. Australian High Commission for Western Samoa. Snap Prining Ltd. Wellington.

Sauvao, L.M. (1996) Action Research on Parents' Involvement in Aoga Amata: Actions Speak Louder than Words in Assessing and Improving Quality in Early Childhood Centres, National Seminar Proceedings. Children's Issues Centre. Dunedin: University of Otago.

Silver, R.A. (1984). Developing cognition through art. In Katz, L. (ed). Current Topics in Early Childhood Education, Volume iv. United States of America: Able Publishing Corporation.

Saville-Troike, M. (1975) Bilingual Children a Resource Document. Arlington, VA: Centre for Applied Linguistics.

Saville-Troike, M. (1982). Language Development. In H.E. Mitzel (5th edition). Encyclopedia of Educational Research, American Educational Research Association. 
Saville-Troike, M. (1982) The Development of Bilingual and Bicultural Competence in Young Children, In Katz, L. Current Topics in Early Childhood Education. Volume iv. United States of America: Able Publishing Corporation.

Schultz, E. (1980) Samoan Proverbial Expressions: Alagaupu Faa - Samoa.

Skutnab-Kangas, T. and Toukomaa, P. (1976) Teaching Migrant Children's Mother Tongue and Learning the Language of the Host Country in the Context of the Sociocultural Situation of the Migrant Family. Helsinki, The Finnish National Commission for UNESCO.

Smith A.B. Barraclough, S. and Sutcliffe, R. (1996) Research Report: Young Children's Conflicts and Teachers' Perspectives on Them. Children's Issues Centre, Manawa Rangahau Tamariki. Dunedin: University of Otago.

Smith, A.B. (1997) Family Transitions: Helping Children Survive Changes in the Family: Unpublished paper presented at the Quality Contexts for Children's Development Seminar, 12 March, 1997, Invercargill.

Stoffel, H.P. (1982) Language maintenance and language shift of the Serbo-Groatian language in a New Zealand Dalmatian community.

Stoke, E (1985) Maori Research and Development: A Discussion paper prepared for the Social Sciences Committee of the National Research Advisory Council .

Sussex, R. (ed) (1982) The Slavic Language in Emigre Communities. Carbondale, U.S.A. Edmondton, Canada: Linguistic Research Inc.

Tamis, A. (1985) Cultural historical and socioeconomic factors affecting the Greek immigrants in Victoria. Journal of Intercultural Studies, Volume 6. No.2. pp 22-58. 
Te Runanga Nui o nga Kura Kaupapa Maori o Aotearoa (Mana Topu). (1998). Including Te Aho Matua into 3155 of the Education Act, 1989. A submission to the Associate Minister of Education, Hon. Tau Henare.

Tupuola, A. (1993) Critical Analysis of Adolescent Development: A Samoan Women's Perspective. Unpublished M.A. Thesis. Wellington Victoria University of Wellington

UNESCO, (1953) The teaching of Modern languages: A volume of studies deriving from the International Seminar organised by the Secretariat of UNESCO at Nuwara Eliya, Ceylon, August 1953.

Verivaki, M. (1990:11) Language Maintenance and Shift in the Greek Community of Wellington. Unpublished M.A. Thesis. Wellington: Victoria University of Wellington.

Willberg, H. (1997) Transition to Schools; Music Helps Learning. Unpublished paper presented at a National Seminarr, Wellington.

Wylie, C. (1996) Five Years Old and Competent. Wellington: New Zealand Council for Education Research. 


\section{GLOSSARY}

\begin{tabular}{|c|c|}
\hline Samoan & English \\
\hline a e & conjunction but \\
\hline aganuu & culture \\
\hline aiga & family \\
\hline Aoga Amata & Samoan Language Nests (Schools Beginning) \\
\hline alofa & love \\
\hline faaaloalo & respect \\
\hline FAGASA & $\begin{array}{l}\text { abreviated name for the National Organisation for the } \\
\text { teaching and learning of Samoan language. }\end{array}$ \\
\hline faafeiloaiga & (1) greeting, (2) welcome \\
\hline faafetai & thank you \\
\hline faamalie & excuse/pardon \\
\hline faalavelavea & intrude \\
\hline faa le agaga & spiritual \\
\hline faa le nuu & village matters \\
\hline faamavae & farewell \\
\hline faamoemoe & (1) task (2) hope, (3) plan \\
\hline faa Samoa & Samoan way/culture \\
\hline fafo & outside \\
\hline fesoasoani & help \\
\hline filifilia & chosen \\
\hline $\mathrm{i}$ & to \\
\hline
\end{tabular}




\begin{tabular}{|c|c|}
\hline i luma & in front \\
\hline i tua & behind \\
\hline lanumeamata & green \\
\hline lanumoana & blue \\
\hline lauga & speech \\
\hline le & the \\
\hline lele & fly \\
\hline lau & $\begin{array}{l}\text { (1)respectful term for results/outcome as in the } \\
\text { discussion of a topic (2) your, (3) thatch/es), } \\
\text { (4) fishing net floats }\end{array}$ \\
\hline lotu & (1) prayer, (2) church service \\
\hline luga & on \\
\hline ma'au & (1) refer (2) labour \\
\hline mafuaaga & (1) reason, (2) cause \\
\hline matai & titled man/woman \\
\hline mumu & red \\
\hline nei & now \\
\hline ni itu & some ways \\
\hline o & of \\
\hline pa'epa'e & white \\
\hline piniki & pink \\
\hline SAASIA & $\begin{array}{l}\text { abbreviated name for the Samoan Association of Aoga } \\
\text { Amata in Aotearoa }\end{array}$ \\
\hline samasama & yellow \\
\hline si'ui & (1) end, (2) conclusion \\
\hline
\end{tabular}


Taiala

taimi

taunuu

toatele

toloa

to maia

totonu

tupuaga

vai

valaaulia

\section{Maori words}

aroha

Kapa Haka

Kura Kaupapa

manaaki

Te Kohanga Reo

Te Whariki

Tikanga

turangawaewae

wairua

whanau
Samoan Language Curriculum

time

arrived/reached

many

(1) wild duck, (2) Australian grey duck

reveal as in thoughts and opinions

inside

(1) genealogy, (2) ancestors

water

invited/invitation

love

Maori term for Polynesian clubs

Maori School

care

Maori Language Nest

(1) Maori name for the Early Childhood Education

Curriculum, (2) woven mat

\section{Custom}

place where you belong

spirit

(1) be born, (2) be in childbed (3) off spring, (4) family group, (5) family 
whanaunga tanga

whakapapa kinship relationship

genealogy 